\title{
Master regulator genes and their impact on major diseases
}

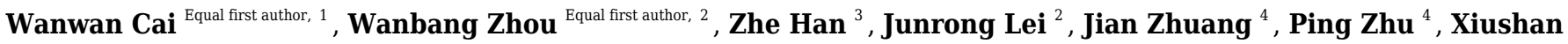 \\ Wu ${ }^{1}$, Wuzhou Yuan ${ }^{\text {Corresp. } 1}$ \\ 1 \\ and Protein Chemistry, College of Life Sciences, Hunan Normal University, Changsha, Hunan, China \\ 2 College of physical education, Hunan Normal University, Changsha, Hunan, China \\ 3 University of Maryland School of Medicine, Center for Precision Disease Modeling, Baltimore, Maryland, USA \\ 4 Guangdong Cardiovascular Institute, Guangdong Provincial People's Hospital, Guangdong Academy of Medical Sciences, Department of Cardiac Surgery, \\ Guangzhou, Guangdong, China \\ Corresponding Author: Wuzhou Yuan \\ Email address: ywz@hunnu.edu.cn
}

Master regulator genes (MRGs) have become a hot topic in recent decades. They not only affect the development of tissue and organ systems but also play a role in other signal pathways by regulating additional MRGs. Because a MRG can regulate the concurrent expression of several genes, its mutation often leads to major diseases. Moreover, the occurrence of many tumors and cardiovascular and nervous system diseases are closely related to MRG changes. With the development in omics technology, an increasing amount of investigations will be directed toward MRGs because their regulation involves all aspects of an organism's development. This review focuses on the definition and classification of MRGs as well as their influence on disease regulation. 
3 Wanwan Cai ${ }^{1 \#}$, Wanbang Zhou ${ }^{2 \#}$, Zhe Han ${ }^{3}$, Junrong Lei ${ }^{2}$, Jian Zhuang ${ }^{4}$, Ping Zhu ${ }^{4}$, Xiushan Wu,

4 Wuzhou Yuan ${ }^{1 *}$

61 The Center for Heart Development, State Key Laboratory of Development Biology of

7 Freshwater Fish, Key Laboratory of MOE for Development Biology and Protein Chemistry,

8 College of Life Sciences, Hunan Normal University, Changsha, Hunan 410081, China;

92 College of physical education, Hunan Normal University, Changsha, Hunan 410081, China;

103 Center for Precision Disease Modeling, University of Maryland School of Medicine, Baltimore,

11 MD 21201.

124 Department of Cardiac Surgery, Guangdong Cardiovascular Institute, Guangdong Provincial

13 People's Hospital, Guangdong Academy of Medical Sciences, Guangzhou, Guangdong 510100,

14 China

15

$16 *$ Corresponding author

17

18 Wuzhou Yuan:ywz@hunnu.edu.cn

19

20

21

22

23 


\section{ABSTRACT}

Master regulator genes (MRGs) have become a hot topic in recent decades. They not only affect the development of tissue and organ systems but also play a role in other signal pathways by regulating additional MRGs. Because a MRG can regulate the concurrent expression of several genes, its mutation often leads to major diseases. Moreover, the occurrence of many tumors and cardiovascular and nervous system diseases are closely related to MRG changes. With the development in omics technology, an increasing amount of investigations will be directed toward MRGs because their regulation involves all aspects of an organism's development. This review focuses on the definition and classification of MRGs as well as their influence on disease regulation.

\section{INTRODUCTION}

Since the discovery of the master regulator genes (MRGs) and the powerful functions of these genes involved in all aspects of tissue and organ development, the study of MRGs have been more and more extensive, and an increasing number of new MRGs have been reported to play key roles in major clinical diseases. In the field of biomedicine, potential MRGs are generally analyzed based on the method of omic technologies, for instance, whole genome transcriptomics ChIPSeq and ATAC-Seq and well established bioinformatic analysis such as GSEA and its variants (Alvarez et al. 2016; Boboila et al. 2018; Lefebvre et al. 2010; Tomljanovic et al. 2018). Recent studies have pointed that the protein called myocyte enhancing factor $2 \mathrm{C}(\mathrm{MEF} 2 \mathrm{C})$ is one of such master regulators involved in the pathogenesis of primary breast cancer. A systematic biological analysis of the transcriptional regulation activity of $\mathrm{MEF} 2 \mathrm{C}$ and its target genes has revealed that this molecule induces collective responses leading to system-level gene expression deregulation and carcinogenesis (Hernández-Lemus et al. 2015). A large number of clinical data from disease samples have been collected to calculate the potential MRGs in their pathological mechanisms. For example, in two breast cancer sample data sets, a systematic implementation of a series of algorithms is used to analyze the MRGs in potential primary breast cancer cells (BacaLópez et al. 2012; Lim et al. 2009; Tapia-Carrillo et al. 2019; Tovar et al. 2015). However, the 
definition of the MRG is still indistinct and imperfect, and a systematic and comprehensive review about MRGs is lacking. In this review, we proposed an updated definition and systematic classification of MRGs, and summarized the role of MRGs in major clinical diseases. The subject presented in this article is written in a descriptive manner instead of a systematic review so that clinicians outside our professional field can understand the basic characteristics of MRGs and their significant effects on clinical diseases.

\section{WHAT IS THE MASTER REGULATOR GENE?}

The term "master regulator gene" introduced by Susumu Ohno in 1978, refers to "the gene at the top of the regulatory hierarchy, which should not be affected by the regulation of any other genes" (Ohno 1978). However, with the increasingly extensive and in-depth study of master regulator genes (MRGs) in recent decades, this definition is no longer an absolute. Many studies have shown that some MRGs can be regulated by others. For example, $m d m 2$ is the master regulator of tumor suppressor protein p53 (Momand et al. 2000), while the p53 gene is a master regulator of diverse cellular processes and a potential therapeutic target for cancer (Farnebo et al. 2010); and snail is the master regulator of epithelial-mesenchymal transition, but it is regulated by Pakl through phosphorylation (Takahashi et al. 2013), which implicates Pakl as a master regulator of epithelial-mesenchymal transition (Yang et al. 2005).

It has been reported that MRGs play a key role via multiple signal pathways. For example, adenosine monophosphate-activated protein kinase (AMPK) regulates the energy balance inside cells by inhibiting adenosine triphosphate (ATP) consumption in the anabolic pathway and enhancing ATP synthesis in the catabolic pathway. When activated by external metabolic pressure, AMPK regulates a complex downstream signal cascade, promoting efficient energy production within the cells (Witczak et al. 2008). Another example is the phosphoinositide 3kinase $(\mathrm{PI} 3 \mathrm{~K}) /$ protein kinase $\mathrm{B}(\mathrm{AKT}) /$ mammalian target of rapamycin (mTOR) signaling pathway. Although this pathway is considered as a master regulator for cancer (Schaefer et al. 2020; Xia \& Xu 2015), mTOR is also considered as a MRG of metabolism (Kim \& Guan 2015; Zeng 2017). Furthermore, it has been reported that the genes for the three transcription factors 
83 Sox2, Oct3/4, and Nanog have been identified as the MRGs that regulate mammalian 84 embryogenesis, embryonic stem cell self-renewal, and pluripotency. These MRGs can bind to 85 enhancer elements in pluripotent embryonic stem cells (ESCs) and recruit mediators to form 86 unusual enhancer domains, which are called super-enhancers. When the MRGs and mediators 87 are simultaneously occupied, the expression programs for most genes in ESCs become co88 activated (Rizzino 2008; Whyte et al. 2013). Phenotypic conditions in living cells are largely

89 determined by the interplay of a multitude of genes and their protein products, which form a 90 gene regulatory network (GRN), and MRGs are the key players in GRNs. Gene regulatory 91 network analysis have shown that different levels of gene regulation are not only related but 92 strongly coupled (Hernández-Lemus et al. 2015). To summarize, MRGs can be updated as genes 93 or signaling pathways that are expressed at the inception of a developmental lineage or a specific 94 cell type, participates in the specification of that lineage by regulating multiple downstream genes' expression either directly or via interacting with other master regulator genes or signaling pathways to form super-enhancers, and critically, when misexpressed, will lead to uncontrolled expression of downstream target genes and MRGs, and have the ability to respecify the fate of cells destined to form other lineages, causing more abnormal development of tissues and organs.

\section{SURVEY METHODOLOGY}

A survey of $>2,000$ articles was carried out using the National Center for Biotechnology Information PubMed database (https:/www.ncbi.nlm.nih.gov/pubmed/) by searching the

102 keyword "master regulator gene". After screening the contents of the abstracts of these literatures, we found that more than 900 articles quoting MRGs covered most species. Key words were extracted and recorded during the abstract reading, including the properties of the MRGs, the signaling pathways involved, the tissues or organs involved, and the diseases caused, etc. All the data was collated and considered effective. If multiple references mentioned a same MRG, we selected recently published papers or well-known journals for reference. These MRGs were systematically classified as either (1) whole-family MRGs, (2) signal pathway MRGs, or (3) tissue- or organ-specific MRGs. 


\section{4. OVERVIEW OF MRGS}

111 Family MRGs refer to a gene family where all members are MRGs. There are two types: either

112 all members have the same function, such as the HOX, MTA, and SREBP families; or different

113 members in the same family may possess different functions, such as the GATA gene family.

114 The HOX family MRGs are all involved in developmental processes, such as embryogenesis and 115 hematopoiesis (Candini et al. 2015; Grier et al. 2005; Magnusson et al. 2007; McGonigle et al.

116 2008; Rice \& Licht 2007; Vogel et al. 2016; Zhang et al. 2015). In mammals, the HOX network

117 consists of 39 genes that exhibit a high degree of sequence similarity, particularly in the

118 homeobox domain. Homeobox genes function as master regulatory transcription factors during 119 development, and their expression is often altered in cancer (Brotto et al. 2020; Li et al. 2020; Qu

120 et al. 2019). Many of the chromosomal translocations associated with acute leukemias involve

121 HOX genes, such as mixed lineage leukemia, which leads to the inappropriate expression of 122 specific HOX gene subsets (Collins \& Thompson 2018; Dickson et al. 2009). In the GATA 123 family, where each member has a different function, GATA1 and GATA2 regulate

124 erythropoiesis and hematopoiesis as MRGs (Bresnick \& Johnson 2019; Castaño et al. 2019;

125 Gutiérrez et al. 2020; Kang et al. 2012; Katsumura et al. 2018; Katsumura et al. 2014; Leonards

126 et al. 2020; Philipsen 2013; Siegwart et al. 2020), GATA3 is an immune response MRG (El-

127 Arabey et al. 2020; Li et al. 2015; Mirlekar 2020; Nicol et al. 2016a; Nomura et al. 2019), and

128 GATA4 regulates embryonic pancreas development (Kondratyeva et al. 2017). Table 1 lists 18

129 major family MRGs. Among them, the CDX, CDK, HSF, MTA, SREBP, Rho, HNF, IL families

130 and the Rab GTPase superfamily contain genes with the same functions. In the PLK, PAX, TBX,

131 SOX, RUNX, IRF, BCL, and C/EBP families, each family member shares similar functions but

132 also performs their own distinct role. In Figure 1, we have summarized typical family MRGs

133 involved in regulation at the cellular level, including CDK Family, Rho Family and PLK Family

134 involved in cell cycle regulation, and BCL Family involved in cell apoptosis, etc. Figure 2 135 summarizes the Family MRGs involved in tissue and organ development, including PAX Family

136 involved in eye development, TBX Family involved in heart development, etc. 
137 The second type of MRGs is signaling pathways MRGs. In this type, either one of the 138 members in the signal pathway is the MRG, such as AMPK from the AMPK signal pathway, 139 which is known as a master regulator of cellular energy metabolism due to its role in regulating 140 glucose, lipid, and protein metabolism. AMPK is an evolutionarily conserved master regulator of 141 metabolism and a therapeutic target in type 2 diabetes. As an energy sensor, AMPK activity is 142 responsive to both metabolic inputs, i.e., the ratio of AMP to ATP and numerous hormonal cues 143 (Cunningham et al. 2014; Witczak et al. 2008). Or more commonly, members of the whole 144 signaling pathway cooperate with each other as MRGs to regulate the development of a series of 145 tissues and organs. For example, the mTOR signaling pathway is a master regulator of cell 146 growth, proliferation and survival, metabolism, and skeletal muscle production in eukaryotes 147 (Donnelly et al. 2017; Zeng 2017). mTOR belongs to the PI3K-related protein kinase family.

148 The mTOR signaling pathway plays a crucial role in the functional recovery of central nervous 149 system trauma, especially for axon regeneration and autophagy, which has an extensive 150 association with apoptosis. Significantly, this pathway is receiving novel concern for its role in 151 the repair and regeneration of traumatic central nervous system injuries, such as traumatic brain 152 injury and spinal cord injury (Lin et al. 2017a). The novel concern for mTOR is also because it is 153 a master regulator of the inflammatory response in immune and non-immune cells and 154 implicated in a number of chronic inflammatory diseases, especially rheumatic diseases, such as 155 systemic lupus erythematosus, rheumatoid arthritis, systemic sclerosis, sjogren syndrome and 156 seronegative spondyloarthropathy (Suto \& Karonitsch 2020). mTOR signaling pathway acts as a 157 master regulator in memory $\mathrm{CD}^{+} \mathrm{T}^{-}$cells, Th17, and NK cells development and their functional 158 properties (Rostamzadeh et al. 2019). Researchers used RNAi system to specifically knockdown 159 mTOR, raptor, S6K1, eIF4E, and FKBP12 expressions in antigenmune $\mathrm{CD}^{+} \mathrm{T}^{-}$cells and the 160 results have demonstrated that $\mathrm{mTOR}$ acts as the key regulator of memory $\mathrm{CD}^{+} \mathrm{T}^{-}$cells 161 differentiation. When mTOR or raptor is knocked down, the expression levels of memory T-cell 162 markers CD127, CD62L, Bcl-2, and CD27 are remarkably elevated. Significant increases in 163 memory $\mathrm{CD}^{+} \mathrm{T}^{-}$cells differentiation after knockdown of $\mathrm{S} 6 \mathrm{~K} 1$ and eIF4E showed that mTOR 
164 exerted its effect through these two downstream molecules (Araki et al. 2009).

165 The major signaling pathways MRGs are presented in Table 2. For example, the 166 transforming growth factor (TGF) $\beta$ signaling pathway is the master regulator of the respiratory

167 system, epithelial-mesenchymal transition and metastasis, and cancer development; Hedgehog 168 signaling is the master regulator of cell differentiation; and the NF- $\kappa \mathrm{B}$ signaling pathway is the 169 master regulator of innate immune and inflammatory signals. It is noteworthy that the Wnt 170 signaling pathway is not only the master regulator of cell development, cell polarization, and

171 brain invasion but also the master regulator of liver-region and multiple renin-angiotensin system 172 genes.

173 The third type of MRGs is tissue- or organ-specific MRGs that regulate the development of

174 different tissue and organ systems. Table 3 summarizes the MRGs associated with tissue/organ 175 specificity, among which SCL/TAL1, VEGF, and PU.1 are the MRGs of hematopoiesis; Sim1 176 and Gcm are the MRGs of Drosophila neurodevelopment; FOXM1, Blimp1, Oct4, and Myc are 177 the MRGs that regulate the cell cycle, B-cell differentiation to plasma cells, embryonic stem cells, 178 and cell performance, respectively; CTCF is the MRG of human epigenetic and genomic spatial 179 tissue; and FOXj1 is the MRG of the ciliary formation program. In bacteria, the MRGs include 180 SinR, CtrA, FlhDC, Fur, CsgD, Spo0A, CcpA, LuxR, and WOR1. Details and other tissue- and 181 organ-specific MRGs are listed in Table 3.

\section{5. REGULATION OF MAJOR DISEASES BY THE MRGs}

183 Since MRGs can concurrently regulate the expression of hundreds of genes, their expression

184 levels must be tightly controlled, otherwise, misexpression or overexpression will exert a 185 considerable impact on the development of affected organisms, resulting in runaway or uncontrolled metabolism and abnormal development in humans.

\section{MRGs regulation of tumors}

188 MRGs have been implicated in the occurrence of different tumors, including gum germ cell tumors, ovarian cancer, colon cancer, rectal cancer, and lung cancer. For example, SOX9,

190 GATA4, PDX1, PTF1a, HNF1b, and GRP78 are master regulators of pancreatic cancer 
191 (Kondratyeva et al. 2017); while Srebp2 (Krycer et al. 2010) and E2F8 (Rohde et al. 1996) are

192 MRGs of prostate cancer; and CDX2 is the master regulator of gastric cancer (Shiotani et al.

193 2008). Nuclear receptors are liver cancer-related (Jakobsson et al. 2012); PD-L1, TGF- $\beta 1$, and

194 IL-10 are the master regulators of cervical cancer (Qin et al. 2017); and Oct4A is the master

195 regulator of ovarian cancer (Samardzija et al. 2017b). Analysis of master regulatory genes may

196 help to understand the most upstream events in phenotypic development, particularly those

197 related to cancer biology.

198 The most extensively studied MRGs are associated with breast cancer and leukemia. Breast

199 cancer is the most common malignant tumor in women. It has been reported that RUNX1

200 encodes the transcription factor of the RUNX family, a new mutation in RUNX gene was

201 discovered in human breast cancer. It was reported that Runx1 was expressed in all

202 subpopulations of mouse mammary epithelial cells (MECs) except for secretory alveolar cells.

203 The conditional knockout of Runx1 in the MECs resulted in the reduction of luminal MECs.

204 Mainly due to a significant reduction in estrogen receptors (ERs), this phenotype could be

205 rescued by the absence of Trp53 or Rb1. The underlying molecular mechanism was explained by

206 RUNX1 inhibiting the expression of Elf5 (the dominant gene in alveolar cells) and regulating the

207 involvement of mature transcription factor or cofactor genes (such as Foxal and Cited1) in the

208 processes of ER synthesis (van Bragt et al. 2014). Many other MRGs have been reported to be

209 associated with the development of breast cancer, including the HOX gene family, sox4, Runx2,

210 AMPK, p53, TGF- $\beta$, microRNA, KDM4B, p16INK4A, BACH1, Snai1, HMGA1, SATB1,

211 HSP90, TRB3, Ddx5 and Ddx17, FGFR2, and AGTR2 (Supplementary Table 1).

212 Another type of widely studied cancer is leukemia, a malignant clonal disease of

213 hematopoietic stem cells. Due to uncontrolled proliferation, differentiation disorder, and blocked

214 apoptosis, clonal leukemia cells proliferate and accumulate in the bone marrow and other

215 hematopoietic tissues, infiltrate other non-hematopoietic tissues and organs, and inhibit normal

216 hematopoietic function. Acute lymphoblastic leukemia (ALL) is the most common form of

217 childhood cancer and is characterized by impaired lymphocyte differentiation, resulting in the 
218 accumulation of immature progenitor cells in the bone marrow, peripheral blood, and

219 occasionally the central nervous system. Although ALL cure rates are close to 90\%, it remains

220 the leading cause of cancer-related mortality in children and young adults. Another extremely

221 prevalent form of leukemia is B-cell precursor (BCP)-ALL, which represents 85\% of cases,

222 while the remaining 15\% involve T-cell precursors. It was reported that BCP-ALL might be

223 caused by the synergistic regulation of transcription factors, such as RUNX1, IKZF1, E2A,

224 EBF1, and PAX5 (Tijchon et al. 2012). The other MRGs associated with leukemia include HOX,

225 GATA, CDX, Pax, C/EBPistic genetic lesions, and key transcriptional targets and pathways

226 (Supplementary Table 1).

\section{Influence of MRGs on cardiovascular diseases}

228 Because cardiovascular disease is the leading cause of death in humans, elucidation of the 229 associated role of MRGs is of immense clinical and social value for the effective prevention and 230 treatment of cardiovascular diseases. The MRGs related to heart disease (Table 4) include TBX5, 231 NuRD, SREBP, MyoD, Class IB PI3K p110 genetic lesions, PI3K, and PITX2, which mainly 232 regulate congenital heart disease, metabolic heart disease, heart failure, arrhythmia, etc.

233 Vascular-related MRGs, which include PKC\&, VEGF, SCL/TAL1, PPAR gamma, PGC-1alpha, 234 SOX9, myocardin, FLYWCH1, PSORSIC3, G3BP1, and Etv2, mainly regulate thrombosis, 235 anemia, atherosclerosis, vascular calcification, coronary artery disease, chronic vascular disease, 236 etc. Others, like, Klotho, thyroid hormones and thyroid-stimulating hormone, and CST were also 237 reported as master regulators of cardiovascular disease.

238 Influence of MRGs on Nervous system diseases

239 Nervous system diseases refer to the diseases that occur in the central nervous system, 240 peripheral nervous system and vegetative nervous system, with sensory, motor, consciousness 241 and vegetative nervous dysfunction as the main manifestations, among which the central nervous 242 system diseases are the most widely studied. The central nervous system disease generally refers 243 to the central nervous system degenerative disease, which refers to a group of diseases produced 244 by the chronic progressive degeneration of the central nervous system. Pathologically, there are 
245 neuronal degeneration and neuron loss in the brain and/or spinal cord. Major diseases include

246 Parkinson's disease, the overall ischemia, stroke, epilepsy, Alzheimer's disease and Huntington's

247 disease, etc. At present, many articles have clarified the important role of master regulator genes

248 in neurodegenerative diseases. For example, REST, a major transcriptional regulator of

249 neurodegenerative diseases, is a transcriptional suppressor that silences target genes through

250 epigenetic remodeling. REST and REST-dependent epigenetic remodeling provide a central

251 mechanism critical to the progressive neuronal degeneration associated with neurologic disorders

252 and diseases including global ischemia, stroke, epilepsy, Alzheimer's and Huntington's disease

253 (Hwang \& Zukin 2018). NRF2 regulation processes as a source of potential drug targets against

254 neurodegenerative diseases (Buendia et al. 2016; Cores et al. 2020). ZCCHC17 is a master

255 regulator of synaptic gene expression in Alzheimer's disease (Tomljanovic et al. 2018). ATF2

256 and PARK2 are transcription factors that act as MRGs in Alzheimer's disease (Vargas et al.

257 2018). The ubiquitin-proteasome system is a master regulator of neural development and the

258 maintenance of brain structure and function (Luza et al. 2020), etc. At present, it has not been

259 reported that there is a specific drug effective for various neurological diseases in the world. For

260 many patients, relevant drugs just only relieve symptoms rather than cure diseases, causing

261 indelible damage to patients' physical and mental health. Exploring novel MRGs working on the

262 nervous system and disclosing the molecular mechanism of nervous system diseases, may

263 become the exciting expect to develop target drugs and therapeutic schedule to achieve special

264 purpose for the treatment of patients.

265 There are still many references on the research of master regulatory genes and other human

266 various diseases. For example, there are some reports on the progress of investigating the

267 influence of MRGs on diseases such as inflammatory bowel disease (Danese 2008a), cartilage

268 disease (Ma et al. 2016), and human diseases related to fibroblasts (Shenoy P et al. 2014). Thus,

269 the influence of MRGs on human diseases has permeated every aspect, and MRGs play a vital

270 role in the clinical research and treatment of human diseases. However, how the MRGs can be

271 used more comprehensively to solve the therapy problems in human diseases is an arduous task 
272 at present.

\section{6. OUTLOOK}

274 With the sustained development in omics technologies, research pertaining to MRGs will

275 continue getting more concern and progress because the involvement of MRGs in all aspects of

276 an organism's development is becoming apparent. Here we demonstrated that MRGs fell within

277 three operating motifs: (1) whole-family MRGs, (2) signaling pathway MRGs, and (3) tissue- or

278 organ-specific MRGs and updated the definition of MRGs as genes or signaling pathways that

279 are expressed at the inception of a developmental lineage or a specific cell type, participates in

280 the specification of that lineage by regulating multiple downstream genes' expression either

281 directly or via interacting with other master regulator genes or signaling pathways to form super-

282 enhancers, and critically, when misexpressed, will lead to uncontrolled expression of

283 downstream target genes and MRGs, and have the ability to respecify the fate of cells destined to

284 form other lineages, causing more abnormal development of tissues and organs. The formidable

285 function of an MRG lies not only in its regulation of the concurrent expression of hundreds of

286 genes but also the diversity of its functions on human diseases.

287 MRGs play important roles in the occurrence of various human diseases (such as cancer,

288 cardiovascular diseases and neurological diseases) and exhibit a great potential to be targets of 289 gene therapies and drugs. Therefore, exploring the MRGs corresponding to the pathological

290 mechanisms of different diseases is particularly critical. At present, there have been many reports

291 on the analysis of potential MRGs through different calculation methods, and subsequent

292 experimental verification, which greatly improves the process of discovering and determining

293 MRGs in the pathogenesis. Of course, the use of MRGs for gene therapy or targeted drugs is still

294 a huge challenge, and its clinical application is also a long process, which requires unremitting

295 efforts of the medical research team. We believe that the day of technological breakthroughs of

296 MRGs will definitely come.

297 References

298 Albert M, Schmitz SU, Kooistra SM, Malatesta M, Morales Torres C, Rekling JC, Johansen JV, 299 Abarrategui I, and Helin K. 2013. The histone demethylase Jarid1b ensures faithful 300 mouse development by protecting developmental genes from aberrant H3K4me3. PLoS 
301

302

303

304

305

306

307

308

309

310

311

312

313

314

315

316

317

318

319

320

321

322

323

324

325

326

327

328

329

330

331

332

333

334

335

336

337

338

339

340

341

genetics 9:e1003461-e1003461.

Alder O, Cullum R, Lee S, Kan AC, Wei W, Yi Y, Garside VC, Bilenky M, Griffith M, Morrissy AS, Robertson GA, Thiessen N, Zhao Y, Chen Q, Pan D, Jones SJM, Marra MA, and Hoodless PA. 2014. Hippo signaling influences HNF4A and FOXA2 enhancer switching during hepatocyte differentiation. Cell reports 9:261-271.

Alvarez MJ, Shen Y, Giorgi FM, Lachmann A, Ding BB, Ye BH, and Califano A. 2016. Functional characterization of somatic mutations in cancer using network-based inference of protein activity. Nature genetics 48:838-847. 10.1038/ng.3593

Araki K, Turner AP, Shaffer VO, Gangappa S, Keller SA, Bachmann MF, Larsen CP, and Ahmed R. 2009. mTOR regulates memory CD8 T-cell differentiation. Nature 460:108112. $10.1038 /$ nature 08155

Aziz A, Liu Q-C, and Dilworth FJ. 2010. Regulating a master regulator: establishing tissuespecific gene expression in skeletal muscle. Epigenetics 5:691-695. 10.4161/epi.5.8.13045

Baca-López K, Mayorga M, Hidalgo-Miranda A, Gutiérrez-Nájera N, and Hernández-Lemus E. 2012. The role of master regulators in the metabolic/transcriptional coupling in breast carcinomas. PloS one 7:e42678. 10.1371/journal.pone.0042678

Bai Y, Xiang X, Liang C, and Shi L. 2015. Regulating Rac in the nervous system: molecular function and disease implication of Rac GEFs and GAPs. BioMed research international 2015:632450-632450.

Ball AS, Chaparian RR, and van Kessel JC. 2017. Quorum Sensing Gene Regulation by LuxR/HapR Master Regulators in Vibrios. Journal of Bacteriology 199. 10.1128/JB.00105-17

Basak P, Sadhukhan P, Sarkar P, and Sil PC. 2017. Perspectives of the Nrf-2 signaling pathway in cancer progression and therapy. Toxicology Reports 4:306-318. https://doi.org/10.1016/j.toxrep.2017.06.002

Biagioni F, Bossel Ben-Moshe N, Fontemaggi G, Canu V, Mori F, Antoniani B, Di Benedetto A, Santoro R, Germoni S, De Angelis F, Cambria A, Avraham R, Grasso G, Strano S, Muti P, Mottolese M, Yarden Y, Domany E, and Blandino G. 2012. miR-10b*, a master inhibitor of the cell cycle, is down-regulated in human breast tumours. EMBO Molecular Medicine 4:1214-1229. 10.1002/emmm.201201483

Binda E, Visioli A, Giani F, Trivieri N, Palumbo O, Restelli S, Dezi F, Mazza T, Fusilli C, Legnani F, Carella M, Di Meco F, Duggal R, and Vescovi AL. 2017. Wnt5a Drives an Invasive Phenotype in Human Glioblastoma Stem-like Cells. Cancer Research 77:9961007.

Boboila S, Lopez G, Yu J, Banerjee D, Kadenhe-Chiweshe A, Connolly EP, Kandel JJ, Rajbhandari P, Silva JM, Califano A, and Yamashiro DJ. 2018. Transcription factor activating protein 4 is synthetically lethal and a master regulator of MYCN-amplified neuroblastoma. Oncogene 37:5451-5465. 10.1038/s41388-018-0326-9

Boogerd CJ, and Evans SM. 2016. TBX5 and NuRD Divide the Heart. Developmental cell $36: 242-244$. 
342 Botchkarev VV, and Haber JE. 2018. Functions and regulation of the Polo-like kinase Cdc5 in

343

344

345

346

347

348

349

350

351

352

353

354

355

356

357

358

359

360

361

362

363

364

365

366

367

368

369

370

371

372

373

374

375

376

377

378

379

380

381

382 the absence and presence of DNA damage. Current Genetics 64:87-96.

Bresnick EH, and Johnson KD. 2019. Blood disease-causing and -suppressing transcriptional enhancers: general principles and mechanisms. Blood advances 3:2045-2056. 10.1182/bloodadvances.2019000378

Brotto DB, Siena ÁDD, de Barros II, Carvalho SdCES, Muys BR, Goedert L, Cardoso C, Plaça JR, Ramão A, Squire JA, Araujo LF, and Silva WAd. 2020. Contributions of HOX genes to cancer hallmarks: Enrichment pathway analysis and review. Tumour biology : the journal of the International Society for Oncodevelopmental Biology and Medicine 42:1010428320918050. 10.1177/1010428320918050

Buendia I, Michalska P, Navarro E, Gameiro I, Egea J, and León R. 2016. Nrf2-ARE pathway: An emerging target against oxidative stress and neuroinflammation in neurodegenerative diseases. Pharmacology \& therapeutics 157. 10.1016/j.pharmthera.2015.11.003

Candini O, Spano C, Murgia A, Grisendi G, Veronesi E, Piccinno MS, Ferracin M, Negrini M, Giacobbi F, Bambi F, Horwitz EM, Conte P, Paolucci P, and Dominici M. 2015. Mesenchymal Progenitors Aging Highlights a miR-196 Switch Targeting HOXB7 as Master Regulator of Proliferation and Osteogenesis. STEM CELLS 33:939-950.

Castaño J, Aranda S, Bueno C, Calero-Nieto FJ, Mejia-Ramirez E, Mosquera JL, Blanco E, Wang X, Prieto C, Zabaleta L, Mereu E, Rovira M, Jiménez-Delgado S, Matson DR, Heyn H, Bresnick EH, Göttgens B, Di Croce L, Menendez P, Raya A, and Giorgetti A. 2019. GATA2 Promotes Hematopoietic Development and Represses Cardiac Differentiation of Human Mesoderm. Stem cell reports 13:515-529. 10.1016/j.stemcr.2019.07.009

Cattenoz PB, and Giangrande A. 2016. Revisiting the role of the Gcm transcription factor, from master regulator to Swiss army knife. Fly 10:210-218. 10.1080/19336934.2016.1212793

Chatterjee A, Cui Y, and Chatterjee AK. 2015. Correction for Chatterjee et al., RsmC of Erwinia carotovora subsp. carotovora Negatively Controls Motility, Extracellular Protein Production, and Virulence by Binding FlhD and Modulating Transcriptional Activity of the Master Regulator, FlhDC. Journal of Bacteriology 197:3848. 10.1128/JB.00735-15

Chen L, Fulcoli FG, Tang S, and Baldini A. 2009. Tbx1 regulates proliferation and differentiation of multipotent heart progenitors. Circulation research 105:842-851.

Chen M, Guo Z, Ju W, Ryffel B, He X, and Zheng SG. 2012. The development and function of follicular helper T cells in immune responses. Cellular \& molecular immunology 9:375379.

Chu F, Kearns DB, Branda SS, Kolter R, and Losick R. 2006. Targets of the master regulator of biofilm formation in Bacillus subtilis. Molecular Microbiology 59:1216-1228.

Collins EM, and Thompson A. 2018. HOX genes in normal, engineered and malignant hematopoiesis. The International journal of developmental biology 62:847-856. 10.1387/ijdb.180206at

Colomba A, and Ridley AJ. 2014. Analyzing the Roles of Rho GTPases in Cancer Cell Migration with a Live Cell Imaging 3D-Morphology-Based Assay. In: Trabalzini L, and 
383

384

385

386

387

388

389

390

391

392

393

394

395

396

397

398

399

400

401

402

403

404

405

406

407

408

409

410

411

412

413

414

415

416

417

418

419

420

421

422

423

Retta SF, eds. Ras Signaling: Methods and Protocols. Totowa, NJ: Humana Press, 327337.

Combes G, Alharbi I, Braga LG, and Elowe S. 2017. Playing polo during mitosis: PLK1 takes the lead. Oncogene 36:4819-4827.

Cores Á, Piquero M, Villacampa M, León R, and Menéndez JC. 2020. NRF2 Regulation Processes as a Source of Potential Drug Targets against Neurodegenerative Diseases. Biomolecules 10. 10.3390/biom10060904

Costa C, Germena G, Martin-Conte EL, Molineris I, Bosco E, Marengo S, Azzolino O, Altruda F, Ranieri VM, and Hirsch E. 2011. The RacGAP ArhGAP15 is a master negative regulator of neutrophil functions. Blood 118:1099-1108.

Courtial N, Smink JJ, Kuvardina ON, Leutz A, Göthert JR, and Lausen J. 2012. Tall regulates osteoclast differentiation through suppression of the master regulator of cell fusion DCSTAMP. The FASEB Journal 26:523-532. 10.1096/fj.11-190850

Cui Y, Chatterjee A, Yang H, and Chatterjee AK. 2008. Regulatory network controlling extracellular proteins in Erwinia carotovora subsp. carotovora: FlhDC, the master regulator of flagellar genes, activates rsmB regulatory RNA production by affecting gacA and hexA (lrhA) expression. Journal of Bacteriology 190:4610-4623. 10.1128/JB.0182807

Cunningham KA, Bouagnon AD, Barros AG, Lin L, Malard L, Romano-Silva MA, and Ashrafi K. 2014. Loss of a neural AMP-activated kinase mimics the effects of elevated serotonin on fat, movement, and hormonal secretions. PLoS genetics 10:e1004394-e1004394.

Danese S. 2008a. VEGF in inflammatory bowel disease: a master regulator of mucosal immunedriven angiogenesis. Digestive and liver disease : official journal of the Italian Society of Gastroenterology and the Italian Association for the Study of the Liver 40:680-683. 10.1016/j.dld.2008.02.036

Danese S. 2008b. VEGF in inflammatory bowel disease: A master regulator of mucosal immunedriven angiogenesis. Digestive and Liver Disease 40:680-683. https://doi.org/10.1016/j.dld.2008.02.036

Datta R, and Paul S. 2015. Plant microRNAs: master regulator of gene expression mechanism. Cell Biology International 39:1185-1190. 10.1002/cbin.10502

Dickson GJ, Lappin TR, and Thompson A. 2009. Complete Array of HOX Gene Expression by RQ-PCR. In: Eric So CW, ed. Leukemia: Methods and Protocols. Totowa, NJ: Humana Press, 369-393.

Ding N, Gao Y, Wang N, and Li H. 2011. Functional analysis of the chicken PPAR $\gamma$ gene 5'flanking region and $\mathrm{C} / \mathrm{EBP} \alpha-m e d i a t e d$ gene regulation. Comparative Biochemistry and Physiology Part B: Biochemistry and Molecular Biology 158:297-303.

Distefano MB, Kjos I, Bakke O, and Progida C. 2015. Rab7b at the intersection of intracellular trafficking and cell migration. Communicative \& integrative biology 8:e1023492e1023492.

Donnelly S, Huston WM, Johnson M, Tiberti N, Saunders B, O'Brien B, Burke C, Labbate M, and Combes V. 2017. Targeting the master regulator mTOR: a new approach to prevent

PeerJ reviewing PDF | (2020:06:49590:1:2:NEW 23 Aug 2020) 
424

425

426

427

428

429

430

431

432

433

434

435

436

437

438

439

440

441

442

443

444

445

446

447

448

449

450

451

452

453

454

455

456

457

458

459

460

461

462

463

464

the neurological of consequences of parasitic infections? Parasites \& vectors 10:581-581. Doostparast Torshizi A, and Wang K. 2017. Deconvolution of Transcriptional Networks in PostTraumatic Stress Disorder Uncovers Master Regulators Driving Innate Immune System Function. Scientific Reports 7:14486-14486.

Du L, Ning Z, Liu F, and Zhang H. 2017. Corepressor metastasis-associated protein 3 modulates epithelial-to-mesenchymal transition and metastasis. Chinese Journal of Cancer 36:28.

Eaton JL, and Glasgow E. 2006. The zebrafish bHLH PAS transcriptional regulator, singleminded $1(\operatorname{sim} 1)$, is required for isotocin cell development. Developmental Dynamics 235:2071-2082. 10.1002/dvdy.20848

El-Arabey AA, Denizli M, Kanlikilicer P, Bayraktar R, Ivan C, Rashed M, Kabil N, Ozpolat B, Calin GA, Salama SA, Abd-Allah AR, Sood AK, and Lopez-Berestein G. 2020. GATA3 as a master regulator for interactions of tumor-associated macrophages with high-grade serous ovarian carcinoma. Cellular signalling 68:109539. 10.1016/j.cellsig.2020.109539

Farnebo M, Bykov VJN, and Wiman KG. 2010. The p53 tumor suppressor: A master regulator of diverse cellular processes and therapeutic target in cancer. Biochemical and Biophysical Research Communications

396:85-89. https://doi.org/10.1016/j.bbrc.2010.02.152

Fazilaty H, Gardaneh M, Bahrami T, Salmaninejad A, and Behnam B. 2013. Crosstalk between breast cancer stem cells and metastatic niche: emerging molecular metastasis pathway? Tumor Biology 34:2019-2030.

Fernandez-Marcos PJ, and Auwerx J. 2011. Regulation of PGC-1 $\alpha$, a nodal regulator of mitochondrial biogenesis. The American journal of clinical nutrition 93:884S-8890. 10.3945/ajen.110.001917

Filone CM, Caballero IS, Dower K, Mendillo ML, Cowley GS, Santagata S, Rozelle DK, Yen J, Rubins KH, Hacohen N, Root DE, Hensley LE, and Connor J. 2014. The Master Regulator of the Cellular Stress Response (HSF1) Is Critical for Orthopoxvirus Infection. PLOS Pathogens 10:e1003904.

Fischer JW. 2009. Protein kinase C delta: a master regulator of apoptosis in neointimal thickening? Cardiovascular Research 85:407-408.

Foroughi Asl H, Talukdar Husain A, Kindt Alida SD, Jain Rajeev K, Ermel R, Ruusalepp A, Nguyen Khanh-Dung H, Dobrin R, Reilly Dermot F, Schunkert H, Samani Nilesh J, Braenne I, Erdmann J, Melander O, Qi J, Ivert T, Skogsberg J, Schadt Eric E, Michoel T, and Björkegren Johan LM. 2015. Expression Quantitative Trait Loci Acting Across Multiple Tissues Are Enriched in Inherited Risk for Coronary Artery Disease. Circulation: Cardiovascular Genetics 8:305-315.

Frohling S, Scholl C, Bansal D, and Huntly BJP. 2007. HOX Gene Regulation in Acute Myeloid Leukemia: CDX Marks the Spot? Cell Cycle 6:2241-2245.

Fry TJ, and Mackall CL. 2001. Interleukin-7: master regulator of peripheral T-cell homeostasis? Trends in Immunology 22:564-571.

Fujita M, and Losick R. 2005. Evidence that entry into sporulation in Bacillus subtilis is governed by a gradual increase in the level and activity of the master regulator Spo0A. 
465

466

467

468

469

470

471

472

473

474

475

476

477

478

479

480

481

482

483

484

485

486

487

488

489

490

491

492

493

494

495

496

497

498

499

500

501

502

503

504

505

Genes \& development 19:2236-2244.

Gómez-Orte E, Sáenz-Narciso B, Moreno S, and Cabello J. 2013. Multiple functions of the noncanonical Wnt pathway. Trends in Genetics 29:545-553.

Garry DJ. 2016. Etv2 IS A MASTER REGULATOR OF HEMATOENDOTHELIAL LINEAGES. Transactions of the American Clinical and Climatological Association 127:212-223.

Gianni-Barrera R, Bartolomeo M, Vollmar B, Djonov V, and Banfi A. 2014. Split for the cure: VEGF, PDGF-BB and intussusception in therapeutic angiogenesis. Biochemical Society Transactions 42:1637-1642.

Golan-Mashiach M, Grunspan M, Emmanuel R, Gibbs-Bar L, Dikstein R, and Shapiro E. 2012. Identification of CTCF as a master regulator of the clustered protocadherin genes. Nucleic acids research 40:3378-3391. 10.1093/nar/gkr1260

Gong X, Qian H, Shao W, Li J, Wu J, Liu J-J, Li W, Wang H-W, Espenshade P, and Yan N. 2016. Complex structure of the fission yeast SREBP-SCAP binding domains reveals an oligomeric organization. Cell Research 26:1197-1211.

González A, Bes MT, Valladares A, Peleato ML, and Fillat MF. 2012. FurA is the master regulator of iron homeostasis and modulates the expression of tetrapyrrole biosynthesis genes in Anabaena sp. PCC 7120. Environmental microbiology 14:3175-3187. 10.1111/j.1462-2920.2012.02897.x

Gora KG, Tsokos CG, Chen YE, Srinivasan BS, Perchuk BS, and Laub MT. 2010. A cell-typespecific protein-protein interaction modulates transcriptional activity of a master regulator in Caulobacter crescentus. Molecular Cell 39:455-467. 10.1016/j.molcel.2010.06.024

Grier DG, Thompson A, Kwasniewska A, McGonigle GJ, Halliday HL, and Lappin TR. 2005. The pathophysiology of HOX genes and their role in cancer. The Journal of pathology 205:154-171.

Grifoni D, and Bellosta P. 2015. Drosophila Myc: A master regulator of cellular performance. Biochimica et biophysica acta 1849:570-581. 10.1016/j.bbagrm.2014.06.021

Gutiérrez L, Caballero N, Fernández-Calleja L, Karkoulia E, and Strouboulis J. 2020. Regulation of GATA1 levels in erythropoiesis. IUBMB life 72. 10.1002/iub.2192

Häcker G, and Vaux DL. 1995. Apoptosis: A sticky business. Current Biology 5:622-624.

Hayes JD, and Dinkova-Kostova AT. 2017. Epigenetic Control of NRF2-Directed Cellular Antioxidant Status in Dictating Life-Death Decisions. Molecular Cell 68:5-7. https://doi.org/10.1016/j.molcel.2017.09.023

Hernández-Lemus E, Baca-López K, and Tovar H. 2015. What Makes a Transcriptional Master Regulator? A Systems Biology Approach.161-174. 10.1007/978-3-319-21687-4_10

Hinds PW. 2003. Cdk2 dethroned as master of S phase entry. Cancer Cell 3:305-307.

Holmberg Olausson K, Nistér M, and Lindström MS. 2012. p53 -Dependent and -Independent Nucleolar Stress Responses. Cells 1:774-798. 10.3390/cells1040774

Hong Y-K, and Detmar M. 2003. Prox1, master regulator of the lymphatic vasculature phenotype. Cell and Tissue Research 314:85-92. 
506 Hu Y, Wang J, Yang B, Zheng N, Qin M, Ji Y, Lin G, Tian L, Wu X, Wu L, and Sun B. 2011.

507

508

509

510

511

512

513

514

515

516

517

518

519

520

521

522

523

524

525

526

527

528

529

530

531

532

533

534

535

536

537

538

539

540

541

542

543

544

545

546 Guanylate Binding Protein 4 Negatively Regulates Virus-Induced Type I IFN and Antiviral Response by Targeting IFN Regulatory Factor 7. The Journal of Immunology 187:6456-6462.

Huja S, Oren Y, Biran D, Meyer S, Dobrindt U, Bernhard J, Becher D, Hecker M, Sorek R, and Ron EZ. 2014. Fur is the master regulator of the extraintestinal pathogenic Escherichia coli response to serum. mBio 5. 10.1128/mBio.01460-14

Hwang J-Y, and Zukin RS. 2018. REST, a master transcriptional regulator in neurodegenerative disease. Current opinion in neurobiology 48:193-200. 10.1016/j.conb.2017.12.008

Ichikawa M, Asai T, Chiba S, Kurokawa M, and Ogawa S. 2004. Runx1/AML-1 Ranks as a Master Regulator of Adult Hematopoiesis. Cell Cycle 3:720-722.

Inoue J, Ihara Y, Tsukamoto D, Yasumoto K, Hashidume T, Kamimura K, Nakai Y, Hirano S, Shimizu M, Kominami R, and Sato R. 2016. Identification of BCL11B as a regulator of adipogenesis. Scientific Reports 6:32750-32750.

Ishida M, E. Oguchi M, and Fukuda M. 2016. Multiple Types of Guanine Nucleotide Exchange Factors (GEFs) for Rab Small GTPases. Cell Structure and Function 41:61-79.

Jakob S, and Lovell-Badge R. 2011. Sex determination and the control of Sox9 expression in mammals. The FEBS Journal 278:1002-1009.

Jakobsson T, Treuter E, Gustafsson J-Å, and Steffensen KR. 2012. Liver X receptor biology and pharmacology: new pathways, challenges and opportunities. Trends in Pharmacological Sciences 33:394-404.

Janky Rs, Binda MM, Allemeersch J, Van den broeck A, Govaere O, Swinnen JV, Roskams T, Aerts S, and Topal B. 2016. Prognostic relevance of molecular subtypes and master regulators in pancreatic ductal adenocarcinoma. BMC Cancer 16:632.

Jaskólska M, and Gerdes K. 2015. CRP-dependent positive autoregulation and proteolytic degradation regulate competence activator Sxy of Escherichia coli. Molecular Microbiology 95:833-845. 10.1111/mmi.12901

Jeffery JM, Kalimutho M, Johansson P, Cardenas DG, Kumar R, and Khanna KK. 2017. FBXO31 protects against genomic instability by capping FOXM1 levels at the G2/M transition. Oncogene 36:1012-1022. 10.1038/onc.2016.268

John SA, and Garrett-Sinha LA. 2009. Blimp1: a conserved transcriptional repressor critical for differentiation of many tissues. Experimental cell research 315:1077-1084. 10.1016/j.yexcr.2008.11.015

Julian LM, McDonald ACH, and Stanford WL. 2017. Direct reprogramming with SOX factors: masters of cell fate. Current Opinion in Genetics \& Development 46:24-36.

Kang J, Yoo J, Lee S, Tang W, Aguilar B, Ramu S, Choi I, Otu HH, Shin JW, Dotto GP, Koh CJ, Detmar M, and Hong Y-K. 2010. An exquisite cross-control mechanism among endothelial cell fate regulators directs the plasticity and heterogeneity of lymphatic endothelial cells. Blood 116:140-150.

Kang Y-A, Sanalkumar R, O'Geen H, Linnemann AK, Chang C-J, Bouhassira EE, Farnham PJ, Keles S, and Bresnick EH. 2012. Autophagy Driven by a Master Regulator of 
547

548

549

550

551

552

553

554

555

556

557

558

559

560

561

562

563

564

565

566

567

568

569

570

571

572

573

574

575

576

577

578

579

580

581

582

583

584

585

586

587

Hematopoiesis. Molecular and Cellular Biology 32:226-239.

Katsumura KR, Mehta C, Hewitt KJ, Soukup AA, Fraga de Andrade I, Ranheim EA, Johnson KD, and Bresnick EH. 2018. Human leukemia mutations corrupt but do not abrogate GATA-2 function. Proceedings of the National Academy of Sciences of the United States of America 115:E10109-E10118. 10.1073/pnas.1813015115

Katsumura KR, Yang C, Boyer ME, Li L, and Bresnick EH. 2014. Molecular basis of crosstalk between oncogenic Ras and the master regulator of hematopoiesis GATA-2. EMBO reports 15:938-947.

Kaul V, and Krams S. 2015. MicroRNAs as master regulators of immune responses in transplant recipients. Current Opinion in Organ Transplantation 20:29-36. 10.1097/MOT.0000000000000148

Kazan K, and Manners JM. 2013. MYC2: the master in action. Molecular plant 6:686-703. $10.1093 / \mathrm{mp} / \mathrm{sss} 128$

Ke ZY, and Yang SJ. 2017. [Role of master transcriptional factor Prox-1 in lymphatic endothelial differentiation of Kaposiform hemangioendothelioma]. Zhonghua bing li xue za zhi = Chinese journal of pathology 46:176-181. 10.3760/cma.j.issn.05295807.2017.03.007

Kim YC, and Guan K-L. 2015. mTOR: a pharmacologic target for autophagy regulation. The Journal of Clinical Investigation 125:25-32.

Kojima H, and Ieda M. 2017. Discovery and progress of direct cardiac reprogramming. Cellular and Molecular Life Sciences 74:2203-2215.

Kondratyeva LG, Chernov IP, Zinovyeva MV, Kopantzev EP, and Sverdlov ED. 2017. Expression of master regulatory genes of embryonic development in pancreatic tumors. Doklady Biochemistry and Biophysics 475:250-252.

Krappmann D, Wegener E, Sunami Y, Esen M, Thiel A, Mordmuller B, and Scheidereit C. 2004. The IkappaB kinase complex and NF-kappaB act as master regulators of lipopolysaccharide-induced gene expression and control subordinate activation of AP-1. Molecular and Cellular Biology 24:6488-6500.

Krycer JR, Sharpe LJ, Luu W, and Brown AJ. 2010. The Akt-SREBP nexus: cell signaling meets lipid metabolism. Trends in Endocrinology \& Metabolism 21:268-276.

Langrish CL, McKenzie BS, Wilson NJ, De Waal Malefyt R, Kastelein RA, and Cua DJ. 2004. IL-12 and IL-23: master regulators of innate and adaptive immunity. Immunological Reviews 202:96-105.

Laub MT, Chen SL, Shapiro L, and McAdams HH. 2002. Genes directly controlled by CtrA, a master regulator of the Caulobacter cell cycle. Proceedings of the National Academy of Sciences of the United States of America 99:4632-4637.

Lee J-E, and Ge K. 2014. Transcriptional and epigenetic regulation of PPAR $\gamma$ expression during adipogenesis. Cell \& bioscience 4:29-29.

Lee S-Y, Kim E-Y, Kim K-H, and Lee K-A. 2016. Bc12110, a new Tpx2 binding partner, is a master regulator of Aurora kinase A in mouse oocytes. Cell cycle (Georgetown, Tex) 15:3296-3305. 
588

589

590

591

592

593

594

595

596

597

598

599

600

601

602

603

604

605

606

607

608

609

610

611

612

613

614

615

616

617

618

619

620

621

622

623

624

625

626

627

628

Lefebvre C, Rajbhandari P, Alvarez MJ, Bandaru P, Lim WK, Sato M, Wang K, Sumazin P, Kustagi M, Bisikirska BC, Basso K, Beltrao P, Krogan N, Gautier J, Dalla-Favera R, and Califano A. 2010. A human B-cell interactome identifies MYB and FOXM1 as master regulators of proliferation in germinal centers. Molecular systems biology 6:377. $10.1038 / \mathrm{msb} .2010 .31$

Lehrke M, and Lazar MA. 2005a. The many faces of PPARgamma. Cell 123:993-999.

Lehrke M, and Lazar MA. 2005b. The Many Faces of PPAR $\gamma$. Cell 123:993-999.

Leonards K, Almosailleakh M, Tauchmann S, Bagger FO, Thirant C, Juge S, Bock T, Méreau H, Bezerra MF, Tzankov A, Ivanek R, Losson R, Peters AHFM, Mercher T, and Schwaller J. 2020. Nuclear interacting SET domain protein 1 inactivation impairs GATA1-regulated erythroid differentiation and causes erythroleukemia. Nature communications 11:2807. 10.1038/s41467-020-16179-8

Levine MS, and Holland Andrew J. 2014. Polo-like Kinase 4 Shapes Up. Structure 22:10711073.

Levy C, Khaled M, and Fisher DE. 2006. MITF: master regulator of melanocyte development and melanoma oncogene. Trends in Molecular Medicine 12:406-414.

Li M, Alsager JS, Wang Z, Cheng L, and Shan B. 2020. Epigenetic upregulation of in non-small lung cancer cells. Aging 12. 10.18632/aging.103597

Li N, Dobrev D, and Wehrens XHT. 2016. PITX2: a master regulator of cardiac channelopathy in atrial fibrillation? Cardiovascular Research 109:345-347.

Li R, Campos J, and Iida J. 2015. A Gene Regulatory Program in Human Breast Cancer. Genetics 201:1341-1348.

Liang Y, Liang Q, Qiao L, and Xiao F. 2020. MicroRNAs Modulate Drug Resistance-Related Mechanisms in Hepatocellular Carcinoma. Frontiers in Oncology 10:920. 10.3389/fonc. 2020.00920

Lim WK, Lyashenko E, and Califano A. 2009. Master regulators used as breast cancer metastasis classifier. Pacific Symposium on Biocomputing Pacific Symposium on Biocomputing:504515.

Lin J, Huo X, and Liu X. 2017a. "mTOR Signaling Pathway": A Potential Target of Curcumin in the Treatment of Spinal Cord Injury. BioMed research international 2017:16348011634801.

Lin S-C, Lee H-C, Hou P-C, Fu J-L, Wu M-H, and Tsai S-J. 2017b. Targeting hypoxia-mediated YAP1 nuclear translocation ameliorates pathogenesis of endometriosis without compromising maternal fertility. The Journal of pathology 242:476-487.

Liston A. 2010. Is foxp3 the master regulator of regulatory T cells? Progress in molecular biology and translational science 92:315-317. 10.1016/S1877-1173(10)92017-6

Liu C-F, Samsa WE, Zhou G, and Lefebvre V. 2017. Transcriptional control of chondrocyte specification and differentiation. Seminars in Cell \& Developmental Biology 62:34-49.

Liu H-c, and Charng Y-y. 2012. Acquired thermotolerance independent of heat shock factor A1 (HsfA1), the master regulator of the heat stress response. Plant Signaling \& Behavior 7:547-550.

Peer) reviewing PDF | (2020:06:49590:1:2:NEW 23 Aug 2020) 
629 Liu Z-J, Semenza GL, and Zhang H-F. 2015. Hypoxia-inducible factor 1 and breast cancer

630

631

632

633

634

635

636

637

638

639

640

641

642

643

644

645

646

647

648

649

650

651

652

653

654

655

656

657

658

659

660

661

662

663

664

665

666

667

668

669 metastasis. Journal of Zhejiang University Science B 16:32-43. 10.1631/jzus.B1400221

Lourenço AR, and Coffer PJ. 2017. SOX4: Joining the Master Regulators of Epithelial-toMesenchymal Transition? Trends in Cancer 3:571-582.

Lu L-F, Li S, Lu X-B, and Zhang Y-A. 2015. Functions of the two zebrafish MAVS variants are opposite in the induction of IFN1 by targeting IRF7. Fish \& Shellfish Immunology 45:574-582.

Lu X, and Kang Y. 2010. Hypoxia and hypoxia-inducible factors: master regulators of metastasis. Clinical cancer research : an official journal of the American Association for Cancer Research 16:5928-5935.

Luza S, Opazo CM, Bousman CA, Pantelis C, Bush AI, and Everall IP. 2020. The ubiquitin proteasome system and schizophrenia. The lancet Psychiatry 7:528-537. 10.1016/S22150366(19)30520-6

Ma Y, Li J, Yao Y, Wei D, Wang R, and Wu Q. 2016. A controlled double-duration inducible gene expression system for cartilage tissue engineering. Scientific reports 6:26617. 10.1038/srep26617

Madison BB. 2016. Srebp2: A master regulator of sterol and fatty acid synthesis. Journal of lipid research 57:333-335.

Magnusson M, Brun ACM, Miyake N, Larsson J, Ehinger M, Bjornsson JM, Wutz A, Sigvardsson M, and Karlsson S. 2007. HOXA10 is a critical regulator for hematopoietic stem cells and erythroid/megakaryocyte development. Blood 109:3687-3696.

Matroule J-Y, Volanti C, and Piette J. 2006. NF-kB in Photodynamic Therapy: Discrepancies of a Master Regulator. Photochemistry and Photobiology 82:1241-1246.

Matsumoto Y, Nagoshi H, Yoshida M, Kato S, Kuroda J, Shimura K, Kaneko H, Horiike S, Nakamura S, and Taniwaki M. 2017. Expression of Master Regulators of T-cell, Helper T-cell and Follicular Helper T-cell Differentiation in Angioimmunoblastic T-cell Lymphoma. Internal medicine (Tokyo, Japan) 56:2851-2856.

McGonigle GJ, Lappin TRJ, and Thompson A. 2008. Grappling with the HOX network in hematopoiesis and leukemia. Frontiers in bioscience : a journal and virtual library. p 4297-4308.

Medina DL, Di Paola S, Peluso I, Armani A, De Stefani D, Venditti R, Montefusco S, ScottoRosato A, Prezioso C, Forrester A, Settembre C, Wang W, Gao Q, Xu H, Sandri M, Rizzuto R, De Matteis MA, and Ballabio A. 2015. Lysosomal calcium signalling regulates autophagy through calcineurin and TFEB. Nature cell biology 17:288-299.

Medvedovic J, Ebert A, Tagoh H, and Busslinger M. 2011. Chapter 5 - Pax5: A Master Regulator of B Cell Development and Leukemogenesis. In: Alt FW, ed. Advances in Immunology: Academic Press, 179-206.

Miranda RC, Pietrzykowski AZ, Tang Y, Sathyan P, Mayfield D, Keshavarzian A, Sampson W, and Hereld D. 2010. MicroRNAs: master regulators of ethanol abuse and toxicity? Alcoholism, clinical and experimental research 34:575-587. 10.1111/j.15300277.2009.01126.x 
670 Mirlekar B. 2020. Co-expression of master transcription factors determines CD4 T cell plasticity

671

672

673

674

675

676

677

678

679

680

681

682

683

684

685

686

687

688

689

690

691

692

693

694

695

696

697

698

699

700

701

702

703

704

705

706

707

708

709

710 and functions in auto-inflammatory diseases. Immunology letters 222:58-66. 10.1016/j.imlet.2020.03.007

Moe Sharon M. 2012. Klotho. Circulation 125:2181-2183.

Molkentin Jeffery D. 2011. The Transcription Factor C/EBP $\beta$ Serves as a Master Regulator of Physiologic Cardiac Hypertrophy. Circulation research 108:277-278.

Momand J, Wu H-H, and Dasgupta G. 2000. MDM2 - master regulator of the p53 tumor suppressor protein. Gene 242:15-29.

Mork L, and Capel B. 2010. Oestrogen shuts the door on SOX9. BMC biology 8:110-110.

Muscariello L, Marino C, Capri U, Vastano V, Marasco R, and Sacco M. 2013. CcpA and three newly identified proteins are involved in biofilm development in Lactobacillus plantarum. Journal of basic microbiology 53:62-71. 10.1002/jobm.201100456

Nascimento FRF, Gomes EA, Russo M, and Lepique AP. 2015. Interferon regulatory factor (IRF)1 is a master regulator of the cross talk between macrophages and L929 fibrosarcoma cells for nitric oxide dependent tumoricidal activity. Plos One 10:e0117782-e0117782.

Nebral K, Denk D, Attarbaschi A, König M, Mann G, Haas OA, and Strehl S. 2009. Incidence and diversity of PAX5 fusion genes in childhood acute lymphoblastic leukemia. Leukemia 23:134-143.

Neurath MF. 2007. IL-23: a master regulator in Crohn disease. Nature Medicine 13:26-27.

Nicol L, Wilkie H, Gossner A, Watkins C, Dalziel R, and Hopkins J. 2016a. Variations in T cell transcription factor gene structure and expression associated with the two disease forms of sheep paratuberculosis. Veterinary Research 47:83.

Nicol L, Wilkie H, Gossner A, Watkins C, Dalziel R, and Hopkins J. 2016b. Variations in T cell transcription factor gene structure and expression associated with the two disease forms of sheep paratuberculosis. Veterinary Research 47:83-83.

Noizet M, Lagoutte E, Gratigny M, Bouschbacher M, Lazareth I, Roest Crollius H, Darzacq X, and Dugast-Darzacq C. 2016. Master regulators in primary skin fibroblast fate reprogramming in a human ex vivo model of chronic wounds. Wound Repair and Regeneration 24:247-262.

Nomura S, Takahashi H, Suzuki J, Kuwahara M, Yamashita M, and Sawasaki T. 2019. Pyrrothiogatain acts as an inhibitor of GATA family proteins and inhibits Th2 cell differentiation in vitro. Scientific reports 9:17335. 10.1038/s41598-019-53856-1

Odom DT, Zizlsperger N, Gordon DB, Bell GW, Rinaldi NJ, Murray HL, Volkert TL, Schreiber J, Rolfe PA, Gifford DK, Fraenkel E, Bell GI, and Young RA. 2004. Control of pancreas and liver gene expression by HNF transcription factors. Science (New York, NY) 303:1378-1381. 10.1126/science.1089769

Ogasawara H, Yamamoto K, and Ishihama A. 2010. Regulatory role of MlrA in transcription activation of csgD, the master regulator of biofilm formation in Escherichia coli. FEMS microbiology letters 312:160-168. 10.1111/j.1574-6968.2010.02112.x

Ogura M, Hashimoto H, and Tanaka T. 2002. Med, a cell-surface localized protein regulating a competence transcription factor gene, comK, in Bacillus subtilis. Bioscience, 
711 Biotechnology, and Biochemistry 66:892-896.

712 Ohno S. 1978. Major sex-determining genes. Monographs on endocrinology 11.

713 Okuno Y, Inoue K, and Imai Y. 2013. Novel insights into histone modifiers in adipogenesis.

$714 \quad$ Adipocyte 2:285-288.

715 P A. 2014. Atypical Rho GTPases RhoD and Rif integrate cytoskeletal dynamics and membrane $716 \quad$ trafficking. Biol Chem 395:477-484.

717 Peng Y-C, and Joyner AL. 2015. Hedgehog signaling in prostate epithelial-mesenchymal growth 718 regulation. Developmental biology 400:94-104.

719 Perino A, Ghigo A, and Hirsch E. 2010. Leukocyte and Cardiac Phosphoinositide 3-Kinase $\gamma$ 720 Activity in Pressure Overload-Induced Cardiac Failure. Trends in Cardiovascular 721

722

723

724

725

726

727

728

729

730

731

732

733

734

735

736

737

738

739

740

741

742

743

744

745

746

747

748

749

750

751

Pfeffer SR. 2017. Rab GTPases: master regulators that establish the secretory and endocytic pathways. Molecular Biology of the Cell 28:712-715.

Philipsen S. 2013. A new twist to the GATA switch. Blood 122:3391-3392.

Pini F, De Nisco NJ, Ferri L, Penterman J, Fioravanti A, Brilli M, Mengoni A, Bazzicalupo M, Viollier PH, Walker GC, and Biondi EG. 2015a. Cell Cycle Control by the Master Regulator CtrA in Sinorhizobium meliloti. PLoS genetics 11:e1005232. 10.1371/journal.pgen.1005232

Pini F, De Nisco NJ, Ferri L, Penterman J, Fioravanti A, Brilli M, Mengoni A, Bazzicalupo M, Viollier PH, Walker GC, and Biondi EG. 2015b. Cell Cycle Control by the Master Regulator CtrA in Sinorhizobium meliloti. PLoS genetics 11:e1005232-e1005232.

Pompeani AJ, Irgon JJ, Berger MF, Bulyk ML, Wingreen NS, and Bassler BL. 2008. The Vibrio harveyi master quorum-sensing regulator, LuxR, a TetR-type protein is both an activator and a repressor: DNA recognition and binding specificity at target promoters. Molecular Microbiology 70:76-88. 10.1111/j.1365-2958.2008.06389.x

Qi Y, Liang Z, Wang Z, Lu G, and Li G. 2015. Determination of Rab5 activity in the cell by effector pull-down assay. Methods in molecular biology (Clifton, NJ) 1298:259-270.

Qiao A, Jin X, Pang J, Moskophidis D, and Mivechi NF. 2017. The transcriptional regulator of the chaperone response HSF1 controls hepatic bioenergetics and protein homeostasis. The Journal of Cell Biology 216:723-741.

Qin Y, Ekmekcioglu S, Forget M-A, Szekvolgyi L, Hwu P, Grimm EA, Jazaeri AA, and Roszik J. 2017. Cervical Cancer Neoantigen Landscape and Immune Activity is Associated with Human Papillomavirus Master Regulators. Frontiers in immunology 8:689-689.

Qu X, Alsager S, Zhuo Y, and Shan B. 2019. HOX transcript antisense RNA (HOTAIR) in cancer. Cancer letters 454:90-97. 10.1016/j.canlet.2019.04.016

Rajagopalan V, and Gerdes AM. 2015. Role of Thyroid Hormones in Ventricular Remodeling. Current Heart Failure Reports 12:141-149.

Rawat VPS, Humphries RK, and Buske C. 2012. Beyond Hox: the role of ParaHox genes in normal and malignant hematopoiesis. Blood 120:519-527.

Relaix F. 2015. Pax genes: Master regulators of development and tissue homeostasis. Seminars in Cell \& Developmental Biology 44:62-63. 
752 Resnick MA, Tomso D, Inga A, Menendez D, and Bell D. 2005. Functional Diversity in the

753

754

755

756

757

758

759

760

761

762

763

764

765

766

767

768

769

770

771

772

773

774

775

776

777

778

779

780

781

782

783

784

785

786

787

788

789

790

791

792 Gene Network Controlled by the Master Regulator p53 in Humans. Cell Cycle 4:10261029. 10.4161/cc.4.8.1904

Rice KL, and Licht JD. 2007. HOX deregulation in acute myeloid leukemia. The Journal of clinical investigation 117:865-868.

Rizzino A. 2008. Transcription factors that behave as master regulators during mammalian embryogenesis function as molecular rheostats. Biochemical Journal 411:e5-e7.

Rohde M, Warthoe P, Gjetting T, Lukas J, Bartek J, and Strauss M. 1996. The retinoblastoma protein modulates expression of genes coding for diverse classes of proteins including components of the extracellular matrix. Oncogene 12:2393-2401.

Rojas JM, Avia M, Martín V, and Sevilla N. 2017. IL-10: A Multifunctional Cytokine in Viral Infections. Journal of immunology research 2017:6104054-6104054.

Rostamzadeh D, Yousefi M, Haghshenas MR, Ahmadi M, Dolati S, and Babaloo Z. 2019. mTOR Signaling pathway as a master regulator of memory CD8 T-cells, Th17, and NK cells development and their functional properties. Journal of cellular physiology 234:12353-12368. 10.1002/jcp.28042

Samardzija C, Greening DW, Escalona R, Chen M, Bilandzic M, Luwor R, Kannourakis G, Findlay JK, and Ahmed N. 2017a. Knockdown of stem cell regulator Oct4A in ovarian cancer reveals cellular reprogramming associated with key regulators of cytoskeletonextracellular matrix remodelling. Scientific reports 7:46312. 10.1038/srep46312

Samardzija C, Greening DW, Escalona R, Chen M, Bilandzic M, Luwor R, Kannourakis G, Findlay JK, and Ahmed N. 2017b. Knockdown of stem cell regulator Oct4A in ovarian cancer reveals cellular reprogramming associated with key regulators of cytoskeletonextracellular matrix remodelling. Scientific Reports 7:46312-46312.

Sandovici I, Hammerle CM, Ozanne SE, and Constância M. 2013. Developmental and environmental epigenetic programming of the endocrine pancreas: consequences for type 2 diabetes. Cellular and Molecular Life Sciences 70:1575-1595.

Satyanarayana A, and Kaldis P. 2009. A dual role of Cdk2 in DNA damage response. Cell Division 4:9.

Sawle AD, Kebschull M, Demmer RT, and Papapanou PN. 2016. Identification of Master Regulator Genes in Human Periodontitis. Journal of dental research 95:1010-1017.

Schönenberger MJ, and Kovacs WJ. 2015. Hypoxia signaling pathways: modulators of oxygenrelated organelles. Frontiers in cell and developmental biology 3:42-42.

Schaefer T, Steiner R, and Lengerke C. 2020. SOX2 and p53 Expression Control Converges in PI3K/AKT Signaling with Versatile Implications for Stemness and Cancer. International journal of molecular sciences 21. 10.3390/ijms21144902

Schmittgen TD. 2010. miR-31: a master regulator of metastasis? Future oncology (London, England) 6:17-20.10.2217/fon.09.150

Schnappauf O, and Aksentijevich I. 2020. Mendelian diseases of dysregulated canonical NF-kB signaling: From immunodeficiency to inflammation. Journal of leukocyte biology 108:573-589. 10.1002/JLB.2MR0520-166R 
793

794

795

796

797

798

799

800

801

802

803

804

805

806

807

808

809

810

811

812

813

814

815

816

817

818

819

820

821

822

823

824

825

826

827

828

829

830

831

832

833

Semenza GL. 2014. Hypoxia-inducible factor 1 and cardiovascular disease. Annual review of physiology 76:39-56. 10.1146/annurev-physiol-021113-170322

Semenza GL. 2017. A compendium of proteins that interact with HIF-1 $\alpha$. Experimental cell research 356:128-135. 10.1016/j.yexcr.2017.03.041

Settembre C, Di Malta C, Polito VA, Garcia Arencibia M, Vetrini F, Erdin S, Erdin SU, Huynh T, Medina D, Colella P, Sardiello M, Rubinsztein DC, and Ballabio A. 2011. TFEB links autophagy to lysosomal biogenesis. Science (New York, NY) 332:1429-1433. 10.1126/science. 1204592

Seymour PA. 2014. Sox9: a master regulator of the pancreatic program. The review of diabetic studies : RDS 11:51-83.

Shaheen R, Al Tala S, Almoisheer A, and Alkuraya FS. 2014. Mutation in encoding a master regulator of centriole formation, defines a novel locus for primordial dwarfism. Journal of Medical Genetics 51:814-816.

Sharma R, Fu SM, and Ju S-T. 2011. IL-2: a two-faced master regulator of autoimmunity. Journal of autoimmunity 36:91-97.

Shenoy P S, Bose B, Sharma M, McFarlane C, and Kambadur R. 2014. Lack of myostatin reduces MyoD induced myogenic potential of primary muscle fibroblasts. Journal of cellular biochemistry 115:1908-1917. 10.1002/jcb.24860

Shinkawa T, Tan K, Fujimoto M, Hayashida N, Yamamoto K, Takaki E, Takii R, Prakasam R, Inouye $\mathrm{S}$, Mezger $\mathrm{V}$, and Nakai A. 2011. Heat shock factor 2 is required for maintaining proteostasis against febrile-range thermal stress and polyglutamine aggregation. Molecular Biology of the Cell 22:3571-3583.

Shiotani A, Kamada T, Yamanaka Y, Manabe N, Kusunoki H, Hata J, and Haruma K. 2008. Sonic hedgehog and CDX2 expression in the stomach. Journal of Gastroenterology and Hepatology 23:S161-S166.

Shubham K, and Mishra R. 2012. Pax6 interacts with SPARC and TGF- $\beta$ in murine eyes. Molecular vision 18:951-956.

Siegwart LC, Schwemmers S, Wehrle J, Koellerer C, Seeger T, Gründer A, and Pahl HL. 2020. The transcription factor NFE2 enhances expression of the hematopoietic master regulators SCL/TAL1 and GATA2. Experimental Hematology 87. 10.1016/j.exphem.2020.06.004

Singh V, Davidson AC, Hume PJ, Humphreys D, and Koronakis V. 2019. Arf GTPase interplay with Rho GTPases in regulation of the actin cytoskeleton. Small GTPases 10:411-418.

Slade L, and Pulinilkunnil T. 2017. The MiTF/TFE Family of Transcription Factors: Master Regulators of Organelle Signaling, Metabolism, and Stress Adaptation. Molecular Cancer Research 15:1637-1643.

Soares E, and Zhou H. 2018. Master regulatory role of p63 in epidermal development and disease. Cellular and molecular life sciences : CMLS 75:1179-1190. 10.1007/s00018017-2701-z

Solomon E, Li H, Duhachek Muggy S, Syta E, and Zolkiewska A. 2010. The role of SnoN in transforming growth factor beta1-induced expression of metalloprotease-disintegrin 
834

835

836

837

838

839

840

841

842

843

844

845

846

847

848

849

850

851

852

853

854

855

856

857

858

859

860

861

862

863

864

865

866

867

868

869

870

871

872

873

874

ADAM12. The Journal of biological chemistry 285:21969-21977.

Stafford GP, Ogi T, and Hughes C. 2005. Binding and transcriptional activation of non-flagellar genes by the Escherichia coli flagellar master regulator FlhD2C2. Microbiology (Reading, England) 151:1779-1788. 10.1099/mic.0.27879-0

Stief A, Altmann S, Hoffmann K, Pant BD, Scheible W-R, and Bäurle I. 2014. Arabidopsis miR156 Regulates Tolerance to Recurring Environmental Stress through SPL Transcription Factors. The Plant Cell 26:1792-1807.

Stolarczyk E, Lord GM, and Howard JK. 2014. The immune cell transcription factor T-bet: A novel metabolic regulator. Adipocyte 3:58-62.

Stowe SD, Olson AL, Losick R, and Cavanagh J. 2014. Chemical shift assignments and secondary structure prediction of the master biofilm regulator, SinR, from Bacillus subtilis. Biomolecular NMR assignments 8:155-158. 10.1007/s12104-013-9473-7

Sun F, Zhang Y, Wang L, Yan X, Tan Y, Guo Z, Qiu J, Yang R, Xia P, and Zhou D. 2012. Molecular characterization of direct target genes and cis-acting consensus recognized by quorum-sensing regulator AphA in Vibrio parahaemolyticus. PloS one 7:e44210. 10.1371/journal.pone. 0044210

Sunadome K, Suzuki T, Usui M, Ashida Y, and Nishida E. 2014. Antagonism between the master regulators of differentiation ensures the discreteness and robustness of cell fates. Molecular Cell 54:526-535. 10.1016/j.molce1.2014.03.005

Sushil KM, Malapaka K, and Nitish RM. 2018. Catestatin: A Master Regulator of Cardiovascular Functions. Current Medicinal Chemistry 25:1352-1374.

Suto T, and Karonitsch T. 2020. The immunobiology of mTOR in autoimmunity. Journal of autoimmunity 110:102373. 10.1016/j.jaut.2019.102373

Suzuki T, Kusakabe M, Nakayama K, and Nishida E. 2012. The protein kinase MLTK regulates chondrogenesis by inducing the transcription factor Sox6. Development 139:2988.

T F. 2017a. Transcriptional regulation of erythropoiesis. Rinsho Ketsueki 58:643-648.

T T. 2017b. Regulation of mononuclear phagocyte development by IRF8. Rinsho Ketsueki 58:798-805.

Takahashi R-u, Takeshita F, Honma K, Ono M, Kato K, and Ochiya T. 2013. Ribophorin II regulates breast tumor initiation and metastasis through the functional suppression of GSK33. Scientific reports 3:2474-2474.

Tapia-Carrillo D, Tovar H, Velazquez-Caldelas TE, and Hernandez-Lemus E. 2019. Master Regulators of Signaling Pathways: An Application to the Analysis of Gene Regulation in Breast Cancer. Frontiers in genetics 10:1180. 10.3389/fgene.2019.01180

Thornton AM, and Shevach EM. 2019. Helios: still behind the clouds. Immunology 158:161-170. 10.1111/imm. 13115

Tijchon E, Havinga J, van Leeuwen FN, and Scheijen B. 2012. B-lineage transcription factors and cooperating gene lesions required for leukemia development. Leukemia 27:541.

Tiwari N, Tiwari Vijay K, Waldmeier L, Balwierz Piotr J, Arnold P, Pachkov M, Meyer-Schaller N, Schübeler D, van Nimwegen E, and Christofori G. 2013. Sox4 Is a Master Regulator of Epithelial-Mesenchymal Transition by Controlling Ezh2 Expression and Epigenetic 
875

876

877

878

879

880

881

882

883

884

885

886

887

888

889

890

891

892

893

894

895

896

897

898

899

900

901

902

903

904

905

906

907

908

909

910

911

912

913

914

915

Reprogramming. Cancer Cell 23:768-783.

Tomljanovic Z, Patel M, Shin W, Califano A, and Teich AF. 2018. ZCCHC17 is a master regulator of synaptic gene expression in Alzheimer's disease. Bioinformatics (Oxford, England) 34:367-371. 10.1093/bioinformatics/btx608

Torre C, Perret C, and Colnot S. 2010. Chapter 5 - Molecular Determinants of Liver Zonation. In: Kaestner KH, ed. Progress in molecular biology and translational science: Academic Press, 127-150.

Tovar H, García-Herrera R, Espinal-Enríquez J, and Hernández-Lemus E. 2015. Transcriptional master regulator analysis in breast cancer genetic networks. Computational Biology and Chemistry 59 Pt B:67-77. 10.1016/j.compbiolchem.2015.08.007

van Bragt MPA, Hu X, Xie Y, and Li Z. 2014. RUNX1, a transcription factor mutated in breast cancer, controls the fate of ER-positive mammary luminal cells. eLife 3:e03881-e03881.

van Kessel JC, Rutherford ST, Shao Y, Utria AF, and Bassler BL. 2013. Individual and combined roles of the master regulators AphA and LuxR in control of the Vibrio harveyi quorum-sensing regulon. Journal of Bacteriology 195:436-443. 10.1128/JB.01998-12

van Nes J, Chan A, van Groningen T, van Sluis P, Koster J, and Versteeg R. 2013. A NOTCH3 Transcriptional Module Induces Cell Motility in Neuroblastoma. Clinical Cancer Research 19:3485-3494.

Vargas DM, De Bastiani MA, Zimmer ER, and Klamt F. 2018. Alzheimer's disease master regulators analysis: search for potential molecular targets and drug repositioning candidates. Alzheimer's research \& therapy 10:59. 10.1186/s13195-018-0394-7

VG K. 2012. [SRY and SOX9: the main genetic factors of mammalian sex determination]. Tsitologiia 54:390-404.

Vivekanandan S, Moovarkumudalvan B, Lescar J, and Kolatkar PR. 2015. Crystallization and Xray diffraction analysis of the HMG domain of the chondrogenesis master regulator Sox9 in complex with a ChIP-Seq-identified DNA element. Acta crystallographica Section F, Structural biology communications 71:1437-1441.

Vogel M, Velleuer E, Schmidt-Jiménez LF, Mayatepek E, Borkhardt A, Alawi M, Kutsche K, and Kortüm F. 2016. Homozygous HOXB1 loss-of-function mutation in a large family with hereditary congenital facial paresis. American Journal of Medical Genetics Part A 170:1813-1819.

Voorhoeve PM. 2010. MicroRNAs: Oncogenes, tumor suppressors or master regulators of cancer heterogeneity? Biochimica et biophysica acta 1805:72-86. 10.1016/j.bbcan.2009.09.003

Vrzalikova K, Woodman CBJ, and Murray PG. 2012a. BLIMP1 $\alpha$, the master regulator of plasma cell differentiation is a tumor supressor gene in B cell lymphomas. Biomedical papers 156:1-6.

Vrzalikova K, Woodman CBJ, and Murray PG. 2012b. BLIMP1 $\alpha$, the master regulator of plasma cell differentiation is a tumor supressor gene in B cell lymphomas. Biomedical papers of the Medical Faculty of the University Palacky, Olomouc, Czechoslovakia 156:1-6. 10.5507/bp.2012.003

Peer] reviewing PDF | (2020:06:49590:1:2:NEW 23 Aug 2020) 
916 Waldner MJ, and Neurath MF. 2014. Master regulator of intestinal disease: IL-6 in chronic 917 inflammation and cancer development. Seminars in immunology 26:75-79. $918 \quad$ 10.1016/j.smim.2013.12.003

919 Wang J, Yang B, Hu Y, Zheng Y, Zhou H, Wang Y, Ma Y, Mao K, Yang L, Lin G, Ji Y, Wu X,

920

921

922

923

924

925

926

927

928

929

930

931

932

933

934

935

936

937

938

939

940

941

942

943

944

945

946

947

948

949

950

951

952

953

954

955

956 and Sun B. 2013. Negative Regulation of Nmi on Virus-Triggered Type I IFN Production by Targeting IRF7. The Journal of Immunology 191:3393-3399.

Watanabe H, Takano K, and Endo T. 2006. [Rho family: master regulators of cytoskeleton and cell migration]. Tanpakushitsu kakusan koso Protein, nucleic acid, enzyme 51:683-692.

Weeks KL1 GX, Du XJ, Boey EJ, Matsumoto A, Bernardo BC, Kiriazis H, Cemerlang N, Tan JW, Tham YK, Franke TF, Qian H, Bogoyevitch MA, Woodcock EA, Febbraio MA, Gregorevic P, McMullen JR. 2012 Phosphoinositide 3-kinase p110 $\alpha$ is a master regulator of exercise-induced cardioprotection and PI3K gene therapy rescues cardiac dysfunction. Circ Heart Fail 5:523-534.

Weeks KL, Gao X, Du X-J, Boey EJH, Matsumoto A, Bernardo BC, Kiriazis H, Cemerlang N, Tan JW, Tham YK, Franke TF, Qian H, Bogoyevitch MA, Woodcock EA, Febbraio MA, Gregorevic P, and McMullen JR. 2012. Phosphoinositide 3-kinase p110 $\alpha$ is a master regulator of exercise-induced cardioprotection and PI3K gene therapy rescues cardiac dysfunction. Circulation Heart failure 5:523-534. 10.1161/CIRCHEARTFAILURE.112.966622

Wehrspaun CC, Haerty W, and Ponting CP. 2015. Microglia recapitulate a hematopoietic master regulator network in the aging human frontal cortex. Neurobiology of aging 36:2443.e2449-2443.e2420. 10.1016/j.neurobiolaging.2015.04.008

Wen Y, Ouyang Z, Devreese B, He W, Shao Y, Lu W, and Zheng F. 2017. Crystal structure of master biofilm regulator $\mathrm{CsgD}$ regulatory domain reveals an atypical receiver domain. Protein science : a publication of the Protein Society 26:2073-2082. 10.1002/pro.3245

Whyte WA, Orlando DA, Hnisz D, Abraham BJ, Lin CY, Kagey MH, Rahl PB, Lee TI, and Young RA. 2013. Master transcription factors and mediator establish super-enhancers at key cell identity genes. Cell 153:307-319.

Wilkie H, Gossner A, Bishop S, and Hopkins J. 2016. Variations in T Cell Transcription Factor Sequence and Expression Associated with Resistance to the Sheep Nematode Teladorsagia circumcincta. Plos One 11:e0149644-e149644.

Wilson SE, and Esposito A. 2009. Focus on molecules: interleukin-1: a master regulator of the corneal response to injury. Experimental eye research 89:124-125. 10.1016/j.exer.2009.02.011

Witczak CA, Sharoff CG, and Goodyear LJ. 2008. AMP-activated protein kinase in skeletal muscle: From structure and localization to its role as a master regulator of cellular metabolism. Cellular and Molecular Life Sciences 65:3737-3755.

Wolański M, Jakimowicz D, and Zakrzewska-Czerwińska J. 2014. Fifty years after the replicon hypothesis: cell-specific master regulators as new players in chromosome replication control. Journal of Bacteriology 196:2901-2911. 10.1128/JB.01706-14

Wu B, Wang J, Zhao Y, and Guo W. 2015. Chapter 5 - Biochemical analysis of Rabin8, the 
957

958

959

960

961

962

963

964

965

966

967

968

969

970

971

972

973

974

975

976

977

978

979

980

981

982

983

984

985

986

987

988

989

990

991

992

993

994

995

996

997

guanine nucleotide exchange factor for Rab8. In: Guo W, ed. Methods in Cell Biology: Academic Press, 59-68.

Wu W, Morrissey CS, Keller CA, Mishra T, Pimkin M, Blobel GA, Weiss MJ, and Hardison RC. 2014. Dynamic shifts in occupancy by TAL1 are guided by GATA factors and drive large-scale reprogramming of gene expression during hematopoiesis. Genome research 24:1945-1962.

Wysokinski D, Pawlowska E, and Blasiak J. 2015. RUNX2: A Master Bone Growth Regulator That May Be Involved in the DNA Damage Response. DNA and Cell Biology 34:305315.

Xia P, and Xu X-Y. 2015. PI3K/Akt/mTOR signaling pathway in cancer stem cells: from basic research to clinical application. American journal of cancer research 5:1602-1609.

Xiao W. 2015. The hypoxia signaling pathway and hypoxic adaptation in fishes. Science China Life Sciences 58:148-155.

Xu Z, Ji G, Shen J, Wang X, Zhou J, and Li L. 2012. SOX9 and myocardin counteract each other in regulating vascular smooth muscle cell differentiation. Biochemical and Biophysical Research Communications 422:285-290.

Yang H, Liang H, Yan J-s, Tao R, Hao S-g, and Ma L-y. 2012. Down-regulation of hematopoiesis master regulator PU.1 via aberrant methylation in chronic myeloid leukemia. International Journal of Hematology 96:65-73. 10.1007/s12185-012-1106-x

Yang Z, Rayala S, Nguyen D, Vadlamudi RK, Chen S, and Kumar R. 2005. Pak1 Phosphorylation of Snail, a Master Regulator of Epithelial-to-Mesenchyme Transition, Modulates Snail's Subcellular Localization and Functions. Cancer Research 65:31793184.

Yu X, Ng CP, Habacher H, and Roy S. 2008. Foxj1 transcription factors are master regulators of the motile ciliogenic program. Nature genetics 40:1445-1453. 10.1038/ng.263

Zago G, Biondini M, Camonis J, and Parrini MC. 2019. A family affair: A Ral-exocyst-centered network links Ras, Rac, Rho signaling to control cell migration. Small GTPases 10:323330.

Zeitz JO, Kaltenböck S, Most E, and Eder K. 2017. Antioxidant status and expression of inflammatory genes in gut and liver of piglets fed different dietary methionine concentrations. Journal of Animal Physiology and Animal Nutrition 101:1166-1174.

Zeng H. 2017. mTOR signaling in immune cells and its implications for cancer immunotherapy. Cancer Letters 408:182-189.

Zhang M-l, Nie F-q, Sun M, Xia R, Xie M, Lu K-h, and Li W. 2015. HOXA5 indicates poor prognosis and suppresses cell proliferation by regulating $\mathrm{p} 21$ expression in non small cell lung cancer. Tumor Biology 36:3521-3531.

Zhang S, Zhang T, Yan M, Ding J, and Chen J. 2014. Crystal structure of the WOPR-DNA complex and implications for Wor1 function in white-opaque switching of Candida albicans. Cell research 24:1108-1120. 10.1038/cr.2014.102

Zhao C, Zeng C, Ye S, Dai X, He Q, Yang B, and Zhu H. 2020. Yes-associated protein (YAP) and transcriptional coactivator with a PDZ-binding motif (TAZ): a nexus between 
998 hypoxia and cancer. Acta pharmaceutica Sinica B 10:947-960. $999 \quad 10.1016 /$ j.apsb.2019.12.010

1000 Zhou F, Li F, Xie F, Zhang Z, Huang H, and Zhang L. 2014. TRAF4 mediates activation of 1001 TGF- $\beta$ signaling and is a biomarker for oncogenesis in breast cancer. Science China Life $1002 \quad$ Sciences 57:1172-1176.

1003 Zhou W, and Sonnenberg GF. 2020. Activation and Suppression of Group 3 Innate Lymphoid $1004 \quad$ Cells in the Gut. Trends in immunology 41:721-733. 10.1016/j.it.2020.06.009

1005 Zhu L, Sun G, Zhang H, Zhang Y, Chen X, Jiang X, Jiang X, Krauss S, Zhang J, Xiang Y, and 1006 Zhang C-Y. 2009. PGC-1alpha is a key regulator of glucose-induced proliferation and 1007 migration in vascular smooth muscle cells. PloS one 4:e4182. $1008 \quad$ 10.1371/journal.pone.0004182

1009 Zona S, Bella L, Burton MJ, Nestal de Moraes G, and Lam EWF. 2014. FOXM1: an emerging 1010 master regulator of DNA damage response and genotoxic agent resistance. Biochimica et

1012 biophysica acta 1839:1316-1322. 10.1016/j.bbagrm.2014.09.016

1013

1014 


\section{Table $\mathbf{1}$ (on next page)}

Table 1. Summary of family MRGs and their related functions

Summary of family MRGs and their related functions 


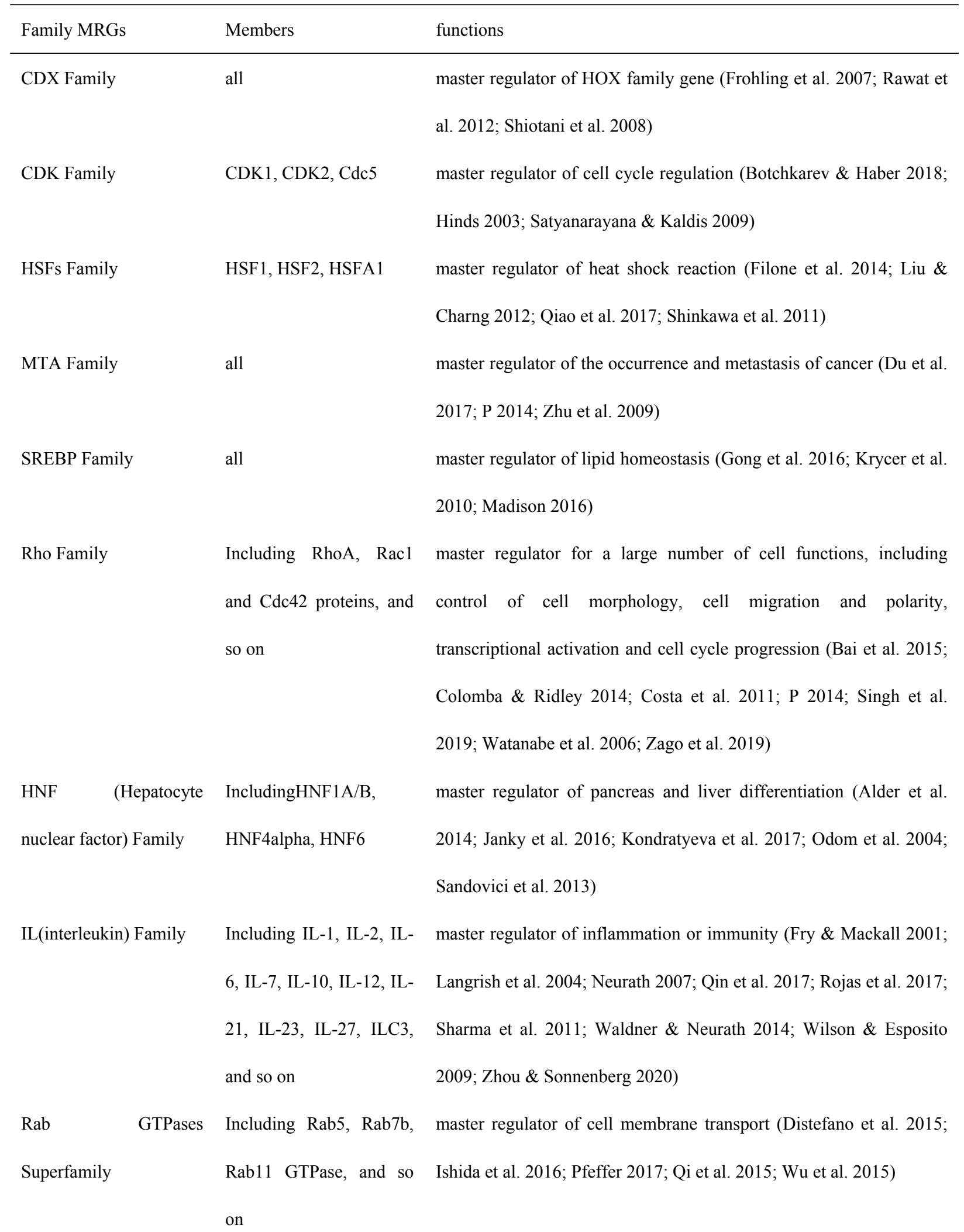




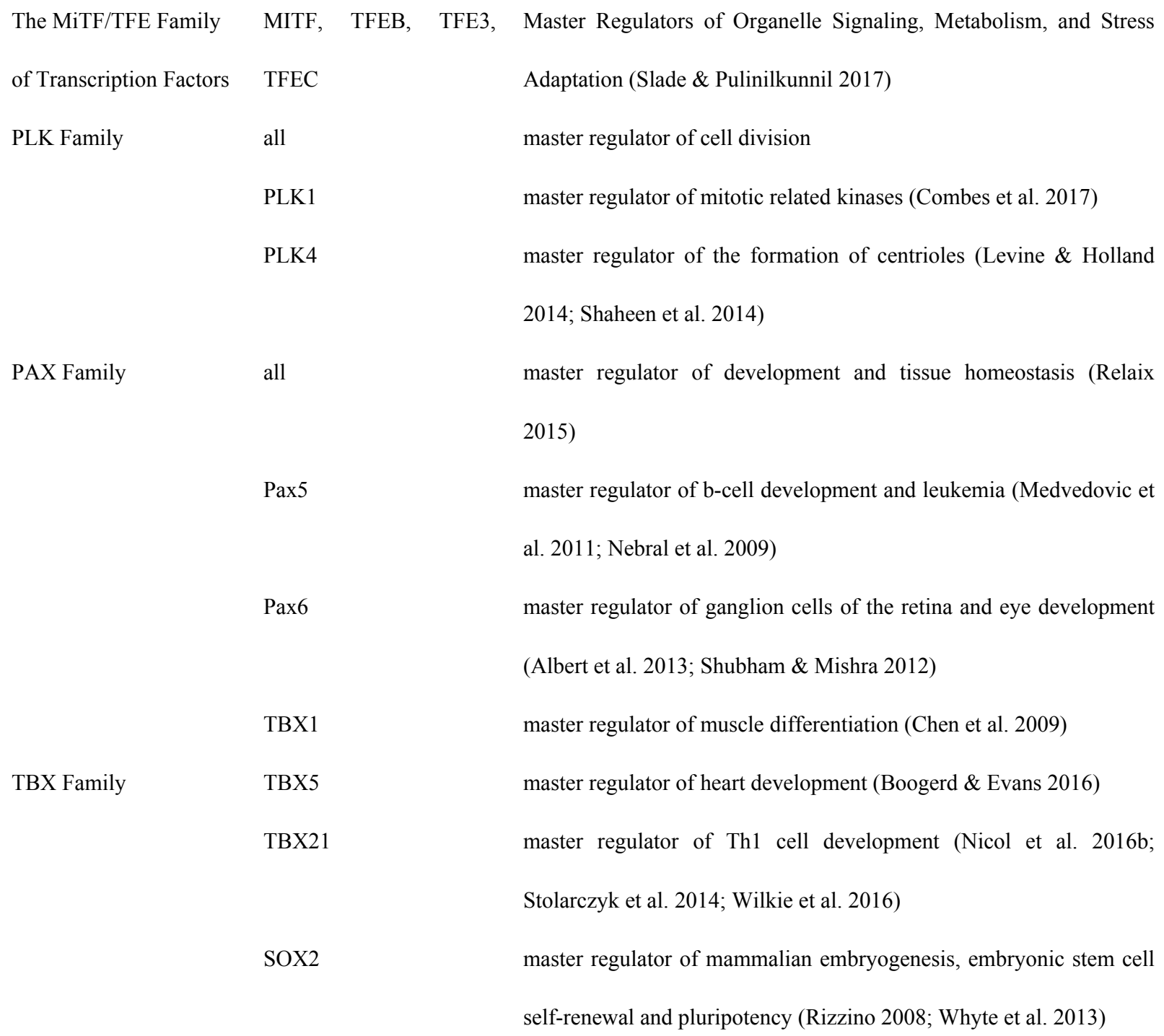

SOX Family 
SOX3

SOX4

Sox 5 , Sox6

SOX9

RUNX Family

IRF Family

IRF-1

IRF4

IRF7

IRF8

Bcl-2 master regulator of innate immunity (Doostparast Torshizi \& Wang 2017)

master regulator of EMT (epithelial-mesenchymal transition) (Lourenço \& Coffer 2017; Tiwari et al. 2013)

the interaction with SOX9 is a master regulator of cartilage development (Ma et al. 2016; Suzuki et al. 2012; Vivekanandan et al. 2015)

master regulator of testis differentiation pathway (Jakob \& LovellBadge 2011; Mork \& Capel 2010; VG 2012)

master regulator of fibroblast differentiation (Noizet et al. 2016)

master regulator of pancreatic program (Julian et al. 2017; Seymour 2014)

SOXB1, SOXE, SOXF master regulator of cell fate (Julian et al. 2017)

RUNX1 master regulator of adult hematopoiesis (Ichikawa et al. 2004; Wehrspaun et al. 2015; Wu et al. 2014)

master regulator of osteoblast lineage (Liu et al. 2017; Wysokinski et al. 2015)

master regulator of cross talk between macrophage and L929 fibrosarcoma cells (Nascimento et al. 2015)

master regulator of human periodontitis (Sawle et al. 2016)

master regulator of IFN-I, virus-induced cytokine (Hu et al. 2011; Lu et al. 2015; Wang et al. 2013)

master regulator of monocytes and dendritic cells development ( $\mathrm{T}$ 2017b)

master regulator of apoptosis (Chen et al. 2012; Häcker \& Vaux 1995) 


\begin{tabular}{|c|c|c|}
\hline \multirow[t]{3}{*}{ BCL Family } & Bcl-6 & master regulator of Tfh cell differentiation (Matsumoto et al. 2017) \\
\hline & BCL11B & master regulator of $\mathrm{T}$ cell $(\mathrm{Th})$ differentiation (Inoue et al. 2016) \\
\hline & $\mathrm{Bcl} 2110$ & master regulator of Aurora kinase a mouse oocytes (Lee et al. 2016) \\
\hline \multirow[t]{4}{*}{ C/EBP Family } & & master regulator of the bone marrow progenitor cells and fat \\
\hline & $\mathrm{C} / \mathrm{EBP} \alpha$ & formation (Ding et al. 2011; Okuno et al. 2013) \\
\hline & & master regulator of physiological cardiac hypertrophy (Molkentin \\
\hline & C/EBPbeta & Jeffery 2011) \\
\hline
\end{tabular}

2 


\section{Table 2 (on next page)}

Table 2. Summary of the important signaling pathways MRGs

Summary of the important signaling pathways MRGs 


\begin{tabular}{|c|c|c|}
\hline Signaling pathway & $\begin{array}{l}\text { master regulator } \\
\text { gene }\end{array}$ & functions \\
\hline TGF- $\beta$ signaling pathway & $\begin{array}{l}\text { TGF- } \beta \text { signaling } \\
\text { pathway }\end{array}$ & $\begin{array}{l}\text { master regulator of the respiratory system, epithelial- } \\
\text { mesenchymal transition and metastasis, and cancer } \\
\text { development, etc (Fazilaty et al. 2013; Solomon et al. } \\
\text { 2010; Zhou et al. 2014) }\end{array}$ \\
\hline PI3K-AKT-mTOR signaling pathway & $\begin{array}{l}\text { PI3K-AKT-mTOR } \\
\text { signaling pathway }\end{array}$ & master regulator of cancer (Xia \& Xu 2015) \\
\hline Hedgehog (Hh) signaling pathway & $\begin{array}{l}\text { Hedgehog }(\mathrm{Hh}) \\
\text { signaling pathway }\end{array}$ & $\begin{array}{l}\text { master regulator of cell differentiation (Peng \& Joyner } \\
\text { 2015) }\end{array}$ \\
\hline NF-kappaB signaling pathway & $\begin{array}{l}\text { NF-kappaB } \\
\text { signaling pathway }\end{array}$ & $\begin{array}{l}\text { master regulator of innate immunity and inflammatory } \\
\text { signaling (Krappmann et al. 2004; Matroule et al. 2006; } \\
\text { Schnappauf \& Aksentijevich 2020; Zeitz et al. 2017) }\end{array}$ \\
\hline & Wnt signal pathway & $\begin{array}{l}\text { master regulator of cell development and cell } \\
\text { polarization (Gómez-Orte et al. 2013) }\end{array}$ \\
\hline Wnt signaling pathway & $\begin{array}{l}\text { Wnt5a } \\
\text { Wnt } / \beta \text {-catenin }\end{array}$ & $\begin{array}{l}\text { master regulator of brain invasion (Binda et al. 2017) } \\
\text { master regulator of the liver region and multiple RAS } \\
\text { (renin-angiotensin system) genes (Torre et al. 2010) }\end{array}$ \\
\hline Notch signaling pathway & Notch3 & $\begin{array}{l}\text { The fate of arteriovenous-lymphatic endothelial cells is } \\
\text { regulated by the master regulator of Notch, COUP-TFII, } \\
\text { and Prox } 1 \text { (Kang et al. 2010) } \\
\text { master regulator of neuroblastoma movement (van Nes } \\
\text { et al. 2013) }\end{array}$ \\
\hline Yap signaling pathway & Yap1 & master regulator of endometriosis (Lin et al. 2017b) \\
\hline Hypoxia signaling pathway & $\begin{array}{l}\text { HIF } 1, \text { HIF- } 1 \alpha \\
\text { HIF- } 2 \alpha\end{array}$ & $\begin{array}{l}\text { master regulators of the adaptive response to hypoxia } \\
\text { (Lu \& Kang 2010; Schönenberger \& Kovacs 2015; Xiao }\end{array}$ \\
\hline
\end{tabular}




\section{Table 3 (on next page)}

Table 3. Summary of reported MRGs and their related functions

Summary of reported MRGs and their related functions 


\begin{tabular}{|c|c|}
\hline MRGs & Related functions \\
\hline SCL/TAL1 & $\begin{array}{l}\text { master regulator of the adult hematopoietic (Courtial et al. 2012; Wehrspaun et al. } \\
\text { 2015) }\end{array}$ \\
\hline VEGF & master regulator of mucosal immunity driving angiogenesis (Danese 2008b) \\
\hline PU.1 & master regulator of hematopoiesis and bone marrow (Yang et al. 2012) \\
\hline Sim 1 & $\begin{array}{l}\text { master regulator of Drosophila neurogenesis (Eaton \& Glasgow 2006) } \\
\text { master regulator of nervous system development in Drosophila, parathyroid } \\
\text { development, master regulator of expression and function regulation in mammals }\end{array}$ \\
\hline Gcm & (Cattenoz \& Giangrande 2016) \\
\hline FOXM1 & $\begin{array}{l}\text { master regulator of different stages of the cell cycle (Jeffery et al. 2017; Zona et al. } \\
\text { 2014) }\end{array}$ \\
\hline Blimp1 & $\begin{array}{l}\text { master regulator of B cell differentiation into plasma cells (John \& Garrett-Sinha } \\
\text { 2009; Vrzalikova et al. 2012b) }\end{array}$ \\
\hline Oct4 & $\begin{array}{l}\text { master regulator of embryonic stem cell self-renewal and pluripotency (Samardzija } \\
\text { et al. } 2017 \mathrm{a} \text { ) }\end{array}$ \\
\hline & $\begin{array}{l}\text { master regulator of cell performance (growth, proliferation, stem cell pluripotency, } \\
\text { ribosomal biogenesis, etc.) (Grifoni \& Bellosta 2015; Holmberg Olausson et al. }\end{array}$ \\
\hline Myc & $\begin{array}{l}\text { 2012; Kazan \& Manners 2013) } \\
\text { master regulator of cellular responses to hypoxia (Liu et al. 2015; Semenza 2014; }\end{array}$ \\
\hline HIF & Semenza 2017) \\
\hline CTCF & $\begin{array}{l}\text { master regulator of human epigenetics and genomic spatial organization (Golan- } \\
\text { Mashiach et al. 2012) }\end{array}$ \\
\hline Foxj1 & master regulator of cilia generation program (Yu et al. 2008) \\
\hline $\operatorname{SinR}$ & $\begin{array}{l}\text { master regulator of Bacillus subtilis biofilm formation (Chu et al. 2006; Stowe et al. } \\
\text { 2014) } \\
\text { master regulator of the cell cycle of the bacillus (Gora et al. 2010; Laub et al. 2002; }\end{array}$ \\
\hline CtrA & $\begin{array}{l}\text { Pini et al. 2015a) } \\
\text { master regulator of flagellar genes (Chatterjee et al. 2015; Cui et al. 2008; Stafford }\end{array}$ \\
\hline FlhDC & et al. 2005) \\
\hline Fur & $\begin{array}{l}\text { master regulator of iron metabolism in Gram-negative bacteria (González et al. } \\
\text { 2012; Huja et al. 2014) }\end{array}$ \\
\hline CsgD & $\begin{array}{l}\text { master regulator of } E \text {. coli biofilm formation (Ogasawara et al. 2010; Wen et al. } \\
\text { 2017) }\end{array}$ \\
\hline & master regulator of the pathogenesis of Bacillus subtilis spore formation (Fujita \& \\
\hline Spo0A & Losick 2005; Wolański et al. 2014) \\
\hline CcpA & $\begin{array}{l}\text { master regulator of carbon catabolism regulation in Bacillus (Muscariello et al. } \\
\text { 2013; Weeks et al. 2012) }\end{array}$ \\
\hline LuxR & master regulator of quorum sensing (Ball et al. 2017; Pompeani et al. 2008) \\
\hline WOR1 & master regulator of white and opaque phenotypes of Candida albicans (Zhang et al. \\
\hline
\end{tabular}




\begin{tabular}{|c|c|}
\hline P53 & $\begin{array}{l}\text { master regulator of human malignant tumors (Farnebo et al. 2010; Resnick et al. } \\
\text { 2005) }\end{array}$ \\
\hline P63 & $\begin{array}{l}\text { master regulator of epidermal development and differentiation(Soares \& Zhou 2018) } \\
\text { master regulator of redox homeostasis (Basak et al. 2017; Cores et al. 2020; Hayes }\end{array}$ \\
\hline Nrf2 & \& Dinkova-Kostova 2017) \\
\hline MITF & $\begin{array}{l}\text { master regulator of melanocyte development (Levy et al. 2006) } \\
\text { master regulator of lysosomal biogenesis and autophagy (Medina et al. 2015; }\end{array}$ \\
\hline TFEB & $\begin{array}{l}\text { Settembre et al. 2011) } \\
\text { master regulator of skeletal muscle gene expression programs (Aziz et al. 2010; }\end{array}$ \\
\hline MyoD & $\begin{array}{l}\text { Sunadome et al. 2014) } \\
\text { master regulator of gene expression in many physiological and pathological }\end{array}$ \\
\hline $\begin{array}{l}\text { MicroRNAs(miR-10b*,miR21, } \\
\text { miR-31,miR153, miR156,etc.) }\end{array}$ & $\begin{array}{l}\text { processes (Biagioni et al. 2012; Datta \& Paul 2015; Kaul \& Krams 2015; Liang et al. } \\
\text { 2020; Miranda et al. 2010; Schmittgen 2010; Stief et al. 2014; Voorhoeve 2010) }\end{array}$ \\
\hline & master regulator of mitochondrial gene expression (Fernandez-Marcos \& Auwerx \\
\hline PGC-1 $\alpha$ & $\begin{array}{l}\text { 2011; Zhu et al. 2009) } \\
\text { master regulator of lymphatic endothelial cell differentiation (Hong \& Detmar 2003; }\end{array}$ \\
\hline Prox1 & Kang et al. 2010; Ke \& Yang 2017) \\
\hline AphA & master regulator of quorum sensing (Sun et al. 2012; van Kessel et al. 2013) \\
\hline PPARgamma & $\begin{array}{l}\text { master regulator of fat formation (Lehrke \& Lazar 2005a; Sunadome et al. 2014) } \\
\text { master regulator of regulatory T (Treg)cell development and function (Liston 2010; }\end{array}$ \\
\hline foxp3 & Thornton \& Shevach 2019) \\
\hline ComK & master regulator of late ability genes (Jaskólska \& Gerdes 2015; Ogura et al. 2002) \\
\hline
\end{tabular}




\section{Table 4 (on next page)}

Table 4. Summary of MRGs related to heart disease

Summary of MRGs related to heart disease 


\begin{tabular}{|c|c|}
\hline MRGs & Cardiovascular disease type \\
\hline TBX5, NuRD & Congenital heart disease (Boogerd \& Evans 2016) \\
\hline SREBP & Treatment of cardiac metabolic diseases (Krycer et al. 2010) \\
\hline VEGF & Vascular disease (Danese 2008b; Gianni-Barrera et al. 2014) \\
\hline MyoD & Heart disease (Kojima \& Ieda 2017) \\
\hline \multirow{2}{*}{ PPAR $\gamma$} & Obesity, diabetes and cardiovascular disease (Lee \& Ge \\
\hline & 2014; Lehrke \& Lazar 2005b) \\
\hline $\mathrm{PKC} \delta$ & Thrombosis complications (Fischer 2009) \\
\hline SCL/TAL1 & Anemia patient ( $\mathrm{T} 2017 \mathrm{a})$ \\
\hline Class IB phosphoinositide 3-kinase p110s & Heart disease (Perino et al. 2010) \\
\hline PI3K & Heart failure (Weeks KL1 2012 ) \\
\hline SOX9 and myocardin & Atherosclerosis, vascular calcification (Xu et al. 2012) \\
\hline Klotho & Cardiovascular diseases (Moe Sharon 2012) \\
\hline \multirow{2}{*}{ PITX2 } & Atrial fibrillation (AF) is the most common persistent \\
\hline & Arrhythmia (Li et al. 2016) \\
\hline FLYWCH1, PSORSIC3, G3BP1 & Coronary artery disease (CAD) (Foroughi Asl et al. 2015) \\
\hline Thyroid hormones (THs) & Cardiovascular diseases (Rajagopalan \& Gerdes 2015) \\
\hline CST & Cardiovascular diseases (CVD) (Sushil et al. 2018) \\
\hline Etv2 & Chronic vascular disease (Garry 2016) \\
\hline
\end{tabular}


Figure 1

Figure 1. Family MRGs associated with cellular level regulation

Family MRGs associated with cellular level regulation

CDK Family、 Rho Family、 PLK Family

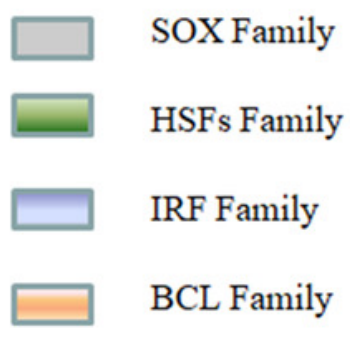

$\square$ Rab GTPases Superfamily

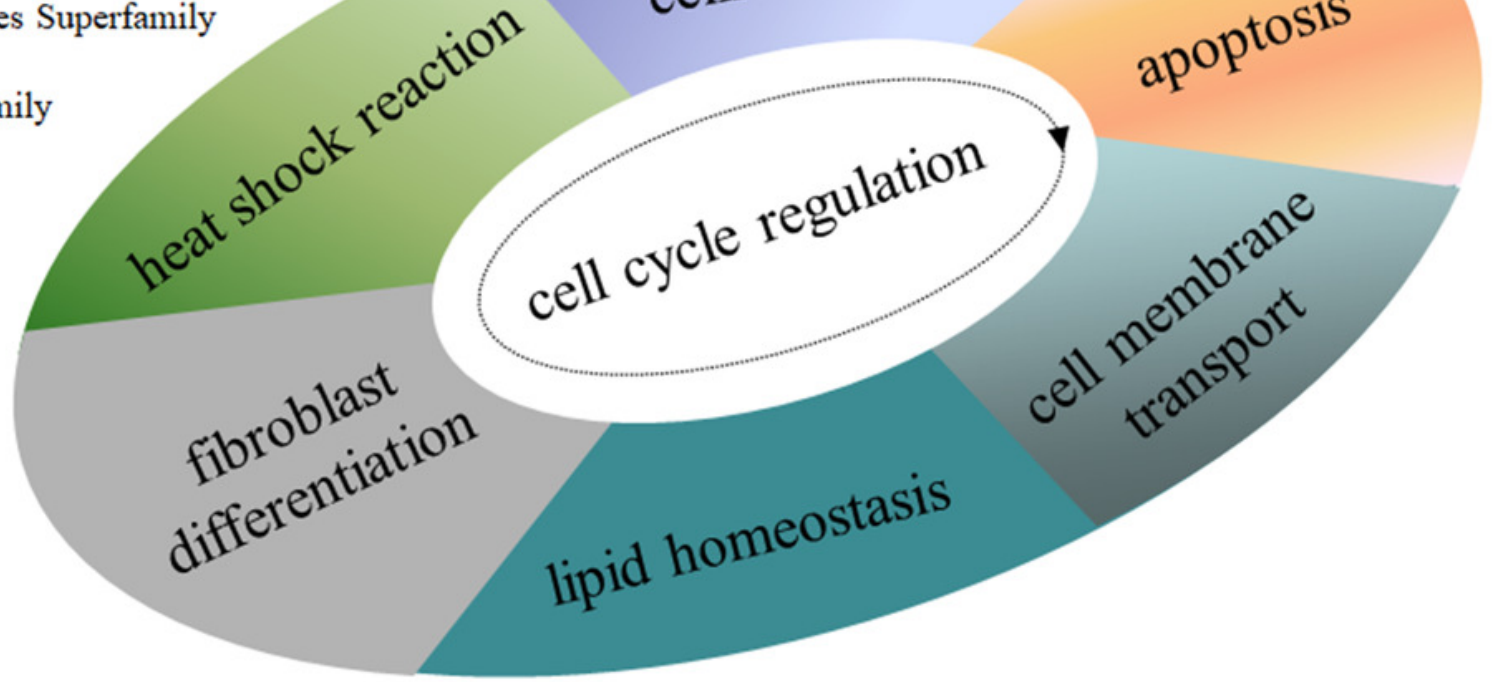

SREBP Family 
Figure 2

Figure 2. Family MRGs involved in tissue and organ development

Family MRGs involved in tissue and organ development

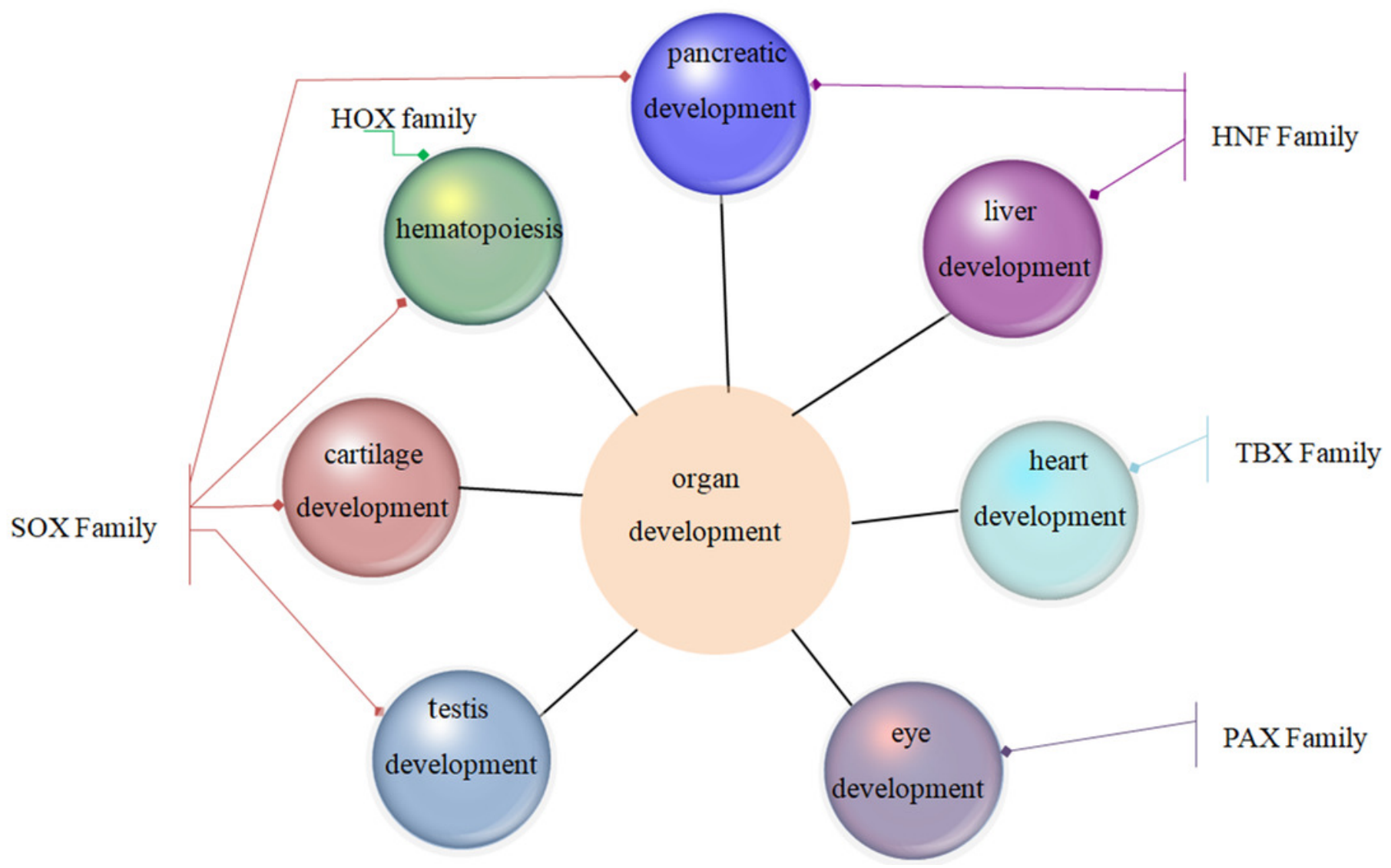

